Bond University

Research Repository

\title{
The Confluence of International Trade and Investment: Exploring the Nexus between Export Controls and Indirect Expropriation
}

\author{
Ghori, Umair \\ Published in: \\ New Zealand Yearbook of International Law
}

DOI:

$10.1163 / 9789004423268$

Licence:

Other

Link to output in Bond University research repository.

Recommended citation(APA):

Ghori, U. (2020). The Confluence of International Trade and Investment: Exploring the Nexus between Export Controls and Indirect Expropriation. In J. J. Bornheim, \& C. Riffel (Eds.), New Zealand Yearbook of International Law (Vol. 16, pp. 76-117). (New Zealand Yearbook of International Law). Brill.

https://doi.org/10.1163/9789004423268

\section{General rights}

Copyright and moral rights for the publications made accessible in the public portal are retained by the authors and/or other copyright owners and it is a condition of accessing publications that users recognise and abide by the legal requirements associated with these rights.

For more information, or if you believe that this document breaches copyright, please contact the Bond University research repository coordinator. 


\title{
The Confluence of International Trade and Investment: Exploring the Nexus between Export Controls and Indirect Expropriation
}

\author{
Umair Ghori*
}

\begin{abstract}
Export controls have received little attention in international trade law. Considering recent decisions in trade disputes involving Chinese control of exports, the area has received renewed interest. This article explores the effect of export controls and their connection with indirect expropriation, especially where export controls are imposed by host states to alleviate shortages. Such controls may prevent a foreign investor from earning revenue through resource exports. The article posits that, in certain situations, export controls can be deemed expropriatory and, therefore, in the settlement of investment disputes between host states and foreign investor, the interpretation of General Agreement on Tariffs and Trade ("GATT")/World Trade Organization ("WTO") jurisprudence on the area may play a useful role because of the ad hoc nature of investor-state dispute settlement ("ISDS") arbitration and due to the lack of precedent in international investment law. However, this role can at best be an initial point, and that space must be reserved for international investment jurisprudence to develop more organically.
\end{abstract}

This article explores the overlap between international trade and investment laws in an area which has begun to receive increased attention. The General Agreement on Tariffs and Trade ("GATT") 1 World Trade Organization ("WTO")

* LlB (Hons), Llm, PhD. Assistant Professor, Faculty of Law, Bond University, Robina QLD 4229 Australia. E-mail: ughori@bond.edu.au. The author wishes to thank Emeritus Professor Mary Hiscock (Bond University) for her mentorship, guidance and feedback on several drafts of this research article. I also thank Professor Muthucumaraswamy Sornarajah (National University of Singapore) and Associate Professor Pasha L Hsieh (Singapore Management University) for their useful comments and feedback. I further thank two anonymous reviewers for their useful suggestions that have greatly improved the article. All errors are mine.

1 See General Agreement on Tariffs and Trade, signed 30 October 1947, 55 UNTS 194 (entered into force 1 January 1948); Marrakesh Agreement Establishing the World Trade Organization, 
framework is mainly oriented towards controlling the import behaviour of wTO Members. This is in line with the prevailing wisdom during various rounds of multilateral trade negotiations, where the overarching objective was to cut import tariffs in order to foster increased trade amongst nations.

Export controls received little attention during the phased construction of the WTO system. It was thought that since countries would be eager to export their outputs for monetary gain, export controls would be limited to circumstances such as national emergencies, natural disasters, famine or times of war. The inadequacies of the GATT/WTO system regarding export controls recently emerged following China's imposition of export restrictions on rare earths and certain raw materials. ${ }^{2}$ However, in the not too distant past, United States ("US") and European textiles interest groups approached their governments to counter India's export controls on cotton because the restrictions were affecting their members' business. ${ }^{3}$ Similarly, Pakistan took extensive efforts to prevent export of cotton yarn in 2009-10 after the local apparel industries complained about a lack of availability of cotton yarn domestically. ${ }^{4}$ In 2018, the then Australian Prime Minister Malcolm Turnbull threatened to impose export quotas in order to convince gas companies to divert part of their output for domestic reserves. ${ }^{5}$ The measures by the Australian government were meant to reduce domestic gas prices, in light of a possible phase

opened for signature 15 April 1994, 1867 UNTS 3 (entered into force 1 January 1995) annex 1 A ("General Agreement on Tariffs and Trade 1994").

2 Appellate Body Report, China - Measures Related to the Exportation of Rare Earths, Tungsten and Molybdenum, wTo Doc WT/DS431/AB/R; WT/DS432/AB/R; WT/DS433/AB/R (7 August 2014); Appellate Body Report, China-Measures Related to the Exportation of Various Raw Materials, wTo Doc WT/DS394/AB/R (30 January 2012).

3 "Global \& Indian Textile Industry Locks Horn Over Cotton Exports", The Economic Times (online, 27 October 2010) <https://economictimes.indiatimes.com/industry/cons-products/ garments-/-textiles/global-indian-textile-industry-locks-horn-over-cotton-exports/article show/6821998.cms $>$.

4 Ahmed Abdullah, "Pakistan: Export Yarn Duty Removed", just-style (Web Page, 27 July 2010) <http://www.just-style.com/news/export-yarn-duty-removed_id108416.aspx?1k=dm>.

5 Fleur Anderson, "Malcolm Turnbull Slaps Export Controls on Recalcitrant Gas Exporters", Australian Financial Review (Web Page, 26 April 2017) <https:/www.afr.com/politics/ malcolm-turnbull-slaps-export-controls-on-recalcitrant-gas-exporters-20170426-gvsuh4>; Louise Yaxley, "Malcolm Turnbull Says Government Will Restrict Gas Exports in Attempt to Lower Power Prices", ABC News (Web Page, 20 June 2017) <http://www.abc.net.au/news/2017o6-2o/government-will-intervene-to-restrict-gas-export:-turnbull/8634674>; see also Henry Belot, "Gas Export Controls on Hold as Government Strikes Deal with Suppliers", ABC News (Web Page, 27 September 2017) <http://www.abc.net.au/news/2017-09-27/gas-export-con trols-on-hold-amid-government-agreement/8993254>. 
out of coal-fired power plants and their substitution with gas-fired power stations. ${ }^{6}$

These measures indicate changing times. Governments appear inclined to use export controls to alleviate local shortages and to achieve domestic policy objectives. The scenario envisaged in this article is based on the large, multinational resource companies that invest in a country to mine, process and export products such as liquefied natural gas ("LNG"), liquefied petroleum gas ("LPG"), fuels and oils. If the government of the host state restricts the ability of the companies to export their output, that may undercut the profit margins of the investor, thereby indirectly expropriating the investment by the foreign investor. Of course, the question of whether indirect expropriation has occurred or not depends on the underlying free trade agreement ("FTA") or bilateral investment treaty ("BIT") which may have led to the initial investment. With this conceptual background, the article explores the larger theme of export controls and their expropriatory effects. The debate cannot be limited to natural resources and commodities only. As the global population grows, trade in agricultural products, food and livestock can be potentially affected by the application of export controls as well. Furthermore, policymakers in resourceexporting countries may be tempted to enact export controls in the form of higher tariffs when the economies graduate to higher value-added sectors. The aim behind such controls is to inwardly divert resources towards nascent value-added sectors in order to enhance their productivity and competitiveness in the international market. When industrial transition towards higher value-added sectors occurs, economies previously reliant on exports of primary production shift their economic policies towards exporting finished goods instead. At this stage, control of exports may assume greater importance and the economic interests of the host countries may conflict with those of existing foreign investors.

This article proceeds as follows: Part 2 of this article briefly covers the use of export controls. Part 3 summarises the WTO rules and jurisprudence on export controls, along with GATT $\operatorname{art} \mathrm{xx}(\mathrm{j})$, which refers to the powers of the wTO member to adopt measures in order to secure or distribute products that are in short supply nationally or locally. Even though the discussion of GATT $\operatorname{art} \mathrm{xx}(\mathrm{j})$ is in the context of the India - Solar Cells ${ }^{7}$ case (a dispute concerning government subsidies), the treatment of $\operatorname{art} \mathrm{xx}(\mathrm{j})$ by the Appellate Body provides us with

6 Ian Verrender, "Gas, Not Coal, the Key to Fixing Australia's Electricity Mess", ABC News (Web Page, 11 September 2017) <http://www.abc.net.au/news/2017-09-11/gas-not-coal-the-fix-toaustralias-soaring-electricity-prices/8890818>.

7 Appellate Body Report, India - Certain Measures Relating to Solar Cells and Solar Modules, wTo Doc WT/DS456/AB/R (16 September 2016) ("India - Solar Cells, Appellate Body Report"). 
useful insights of how the WTO treats the question of local or general short supply, which may be one of the possible rationales for the imposition of export controls. Part 4 explores the possible connection between investment and export controls. In addition to briefly discussing various doctrines explaining indirect expropriation, this part constructs simulated scenarios to illustrate the premise that when foreign investors particularly invest in a country with a view to exporting the output of their operations, any governmental measures interfering with exports become expropriatory in nature. The aim behind simulated scenarios is to illustrate the use of export controls vis-à-vis foreign investments in the absence of no known disputes and/or cases on the area.

Taken on a basic plane, foreign investment based on the export-driven model presumes that the function of the investment is to generate profits through the process of export. Any restriction by the host state that undercuts the profitability of the venturers may amount to indirect expropriation. Part 5 of the article offers an analysis based on the question of what role GATT/WTO jurisprudence will play in the adjudication of future investment disputes arising based on export controls. To answer this question, Part 5 explores two paths, the first path involving parallel actions in the realm of international trade and international investment law, and the second path involving consideration of importing interpretative norms and standards from the GATT/WTO jurisprudence in settlement of any future investment disputes on export controls. Part 6 concludes.

Overall, this article surmises that any future investment disputes involving export controls will borrow heavily from GATT/WTO jurisprudence in the settlement of disputes and wTo Dispute Settlement Body ("DSB") decisions such as India - Solar Cells may play an important interpretative role if export controls have been imposed to alleviate a local or general short supply of materials.

Countries may use export controls to alleviate shortages of essential food and raw materials during testing times. In the past, the food price increased internationally whenever major supplier countries restricted its export to meet domestic demand. For example, the US imposed export controls on grains and fodder in 1973 to maintain domestic prices for animal feed. The flow-on effects of export controls were felt in Japan, which was dependent on such imports from the US. ${ }^{8}$

8 Mitsuo Matsushita, "Export Controls of Natural Resources and the WTo/GATt Disciplines" (2011) 6(2) Asian Journal of WTO \& International Health Law \& Policy 281, 284. 
Export controls are also used to prevent proliferation of weapons and military technology. ${ }^{9}$ Importers and exporters must be aware of any international sanctions, controls and monitoring mechanisms. Another example can be the export control of nuclear materials, which makes the export of nuclear weapons-related materials difficult. ${ }^{10}$ The idea behind such control is not outright banning or prevention, but, rather, to increase the opportunity cost behind the transaction.

Another application of export control is prevention of trade in resources that result from exploitation such as slavery or that come from conflict zones. ${ }^{11}$ Such controls make commerce and transactions difficult so that costs become prohibitively high. Export controls may also used in order to conserve archaeological and/or cultural artefacts or the environment, or in relation to trade affecting endangered species. ${ }^{12}$ These are all specialised applications of export controls. The focus of this article, however, is on the economic aspect of export controls as manifested in international trade and investment law. In international trade, export controls may appear as quotas or increased export taxes. Export controls can also be achieved indirectly through reduced production of materials, which automatically leaves little for export. If there is little or no domestic consumption of the material in question, then there is effectively no export control. Price maintenance and affecting the availability and management of resources can also be potential uses of export controls. Governments often

9 See, eg, "Materiel Export Control", Department of Defence (Web Page) <http://www .defence.gov.au/CASG/DoingBusiness/Internationalengagementandexportsupport/ Materiel\%2oexport\%2ocontrol.asp>; see also "Strategic Export Control in 2016: Military Equipment and Dual-Use Items", Government Offices of Sweden (Web Page, 3 November 2017) <http://www.government.se/legal-documents/2017/11/strategic-export-control-in$2016 />$.

10 Lynn E Davis, "Arms Control, Export Regimes and Multilateral Cooperation" in Zalmay Khalilzad, John White and Andy Marshall (eds), Strategic Appraisal: The Changing Role of Information in Warfare (RAND Corporation, 1999) 361, 364-365; see generally Ian Anthony, Christer Ahlström and Vitaly Fedchenko, Reforming Nuclear Export Controls: The Future of the Nuclear Suppliers Group (SIPRI Research Report No 22, 2007).

11 Organisation of Economic Co-operation and Development, "Regulatory Transparency in Multilateral Agreements Controlling Exports of Tropical Timber, E-Waste and Conflict Diamonds" (Trade Policy Paper No 141, 10 December 2012).

12 See e.g. Nordic Council of Ministers, Illicit Trade in Cultural Artefacts: Stronger TogetherHow can the Nordics Join Forces to Stop the Illegal Import and Export of Cultural Objects (Report, 2017) 49-51; see also Neil Brodie and Isber Sabrine, "The Illegal Excavation and Trade of Syrian Cultural Objects: A View From the Ground" (2017) 53(1) Journal of Field Archaeology 74, 82; Rosalind Reeve, Policing International Trade in Endangered Species: the cITEs Treaty and Compliance (Earthscan, 2002) 549. 
resort to restrictions on exports to ensure availability of materials and goods at a certain price level. Another aspect of price maintenance is when states or groups of states that have common interests in trading in a commodity impose export controls to regulate prices (for example, countries in the Organization of the Petroleum Exporting Countries ("OPEC") frequently meet to discuss production and exports of petroleum to maintain pricing levels).

\subsection{Overview}

Export controls were largely ignored during negotiations for the GATT 1947 (the predecessor of GATT 1994) because of the singular attention given to the reduction of trade barriers and the cutting of high import tariffs ${ }^{13}$ Export controls appear within GATT 1994 rather esoterically as a "prohibition on quantitative restrictions" (GATT art XI). Therefore, the GATT/WTO framework treats export quotas similarly to import quotas in that it prohibits quotas in its application to both imports and exports. However, the specified prohibition on quotas under art XI is qualified by several exceptions. GATT art XI(2)(a) allows WTO members to restrict exports temporarily in order "to relieve critical shortages of foodstuffs" or other "essential" products, while GATT art XI(2)(b) allows the WTO Members to apply technical standards for the classification, grading or marketing of commodities in international trade.

Export controls are further affected by GATT art Xx, which enables wTO members to adopt exceptional measures. GATT art Xx exceptions are further qualified by an additional requirement appearing in the chapeau to the said provision. The chapeau states that any measures adopted by WTO members in line with the general exceptions shall not be arbitrary or discriminatory "between countries where the same conditions prevail". The chapeau clearly states that the exceptions provided under art Xx must not be employed as a "disguised" form of restrictions on international trade.

Export controls are also permissible under GATT art XxI(b)(iii), which enables wTо Members to maintain trade restrictions in times of war or national emergencies. Some commentators allude to the ineffectiveness of the GATT art

13 Mitsuo Matsushita, "Export Control of Natural Resources: wTo Panel Ruling on the Chinese Export Restrictions of Natural Resources" (2011) 3(2) Trade, Law \& Development 268, 270; Bin Gu, "Mineral Export Restraints and Sustainable Development: Are Rare Earths Testing the WTO's Loopholes?” (2011) 4(4) Journal of International Economic Law 765, 784. 
XI prohibition on export quotas by pointing out the high number of accompanying exceptions. ${ }^{14}$

Export tariffs can constitute an additional element of export controls. However, export tariffs are different from import tariffs because of GATT art II(1)(b), which imposes a limitation on the tariff levels which wTо members may place on imports above the concession rates. By comparison, export tariffs do not usually have such restrictions. Hence, wTO members can impose tariff-based export restraints. ${ }^{15}$ Export tariffs as export controls are not prohibited per se under wTO law unless the tariffs are prohibitively high. ${ }^{16}$ Effectively, this means that export tariffs can be used for actual export control or revenue generation by countries. However, if export duties reach a prohibitive level, then this essentially translates into zero-export quotas which falls within the coverage of GATT art XI's prohibition on quotas. ${ }^{17}$

GATT art XX is another provision that affects export controls. This provision allows Wто members to derogate from their obligations. In availing the exceptions, the foremost issue for the party invoking exceptions under GATT art XX is to satisfy the standard of proof. Cases such as EC - Tariff Preferences and US - Shrimp demonstrate that the standard of proof rests on the invoking party (the WTO member adopting export controls). ${ }^{18}$ The country maintaining controls must demonstrate upon challenge that the justification for imposing the measure meets the exceptions outlined in GATT art xx. Additionally, the requirement of the chapeau must also be satisfied. The order of the burden of proof was clarified by the wTO Appellate Body in the US - Shrimp case. Firstly, the country maintaining the impugned measures must demonstrate that the measures fall within one of the GATT art xx exceptions. Secondly,

14 John H Jackson et al, Legal Problems of International Economic Relations (West Publishing, 3rd ed, 1995) 946, cited in Matsushita, "Export Control of Natural Resources: wTo Panel Ruling on the Chinese Export Restrictions of Natural Resources" (n 13) 272 and Matsushita, "Export Controls of Natural Resources and the wTo/GATT Disciplines" (n 8) 288.

15 Matsushita, "Export Control of Natural Resources: wTo Panel Ruling on the Chinese Export Restrictions of Natural Resources" (n 13) 273.

16 Ibid; see also Julia Ya Qin, "Reforming wTo Discipline on Export Duties: Sovereignty over Natural Resources, Economic Development and Environmental Protection” (2012) 46(5) Journal of World Trade 1147, 1153 .

17 Matsushita, "Export Control of Natural Resources: wTo Panel Ruling on the Chinese Export Restrictions of Natural Resources" (n 13) 273; Ya Qin (n 16) 1153.

18 Appellate Body Report, European Communities - Conditions for the Granting of Tariff Preferences to Developing Countries, wTo Doc WT/DS246/AB/R (7 April 2004) [95] ("EC Tariff Preferences, Appellate Body Report"); Appellate Body Report, United States - Import Prohibition of Shrimp and Certain Shrimp Products, wTo Doc WT/DS58/AB/R (12 October 1998) [158] ("US - Shrimp, Appellate Body Report"). 
the requirement of the chapeau must be fulfilled. Therefore, the order of application is to satisfy one of the exceptions under GATT art Xx and then the chapeau. ${ }^{19}$

GATT art XX exceptions (b) and (g) have been the subject of the most usage and disputes in the wто. Exceptions (b) and (g) are not the subject of discussion in this article, because where a country is attempting to alleviate shortfall of materials or resources, exception ( $\mathrm{j}$ ) becomes relevant, especially where export controls are concerned.

Exception ( $\mathrm{j}$ ) is the emerging category that has seen use only once as a defence in wTo dispute settlement proceedings. This occurred in the India Solar Cells case, where India cited exception (j) along with exception (d) in defence of its solar panel subsidy measures which were challenged by the $\mathrm{US}^{20}$

\subsection{The India - Solar Cells case and Exception $(j)$}

The case did not actually broach the question of export controls. Rather, it concerned government subsidies for solar industries. The case becomes relevant here for two reasons. Firstly, it is the only case in wTO jurisprudence where the question of securing or distributing products in short supply is discussed. Secondly, GATT art $\mathrm{xx}(\mathrm{j})$ may form the basis of exceptional arguments that WTO members can adopt when imposing export controls to secure or distribute products in short supply.

The Appellate Body, in determining the question of "short supply", stated that due regard must be given to the total quantity of imports that may be available to meet the necessary supply in a particular geographical area or market. ${ }^{21}$ This may mean assessing whether international supply of the product is stable, which in turn considers "distance between a particular geographical area or market and productions sites" and "the reliability of local or transnational supply chains". 22

19 US - Shrimp, Appellate Body Report (n 18) [118]-[121].

20 Panel Report, India - Certain Measures Relating to Solar Cells and Solar Modules, wTo Doc WT/DS456/R (24 February 2016) [7.3.1]-[7.3.2] ("India - Solar Cells, Panel Report").

21 The Appellate Body held that art $\mathrm{xx}(\mathrm{j})$ reflects a balance of different considerations that must be considered in assessing the question of "general or local short supply". Such considerations include the level of domestic production of the product in question, the nature of products in "general or local short supply", geographical market, price fluctuations, the purchasing power of domestic and foreign consumers and the role played by domestic and foreign producers in the market including "the extent to which domestic producers sell their production abroad": India - Solar Cells, Appellate Body Report (n 7) [6.4]. Ibid. 
The Appellate Body further clarified that whatever factors are relevant depends on the peculiarities of each case. ${ }^{23}$ Regardless of the factors that may be applicable, the party adopting the measure must demonstrate that "available" supply, from both domestic and international sources, is insufficient to meet demand. ${ }^{24}$

Note that the criteria from India - Solar Cells must be balanced with GATT art XI 2(a)-(b), GATT art Xx(j) and its chapeau or GATT art XXI(b)(iii). The criteria seem open and adaptable enough to be applied to potential situations encountered in the future. However, the Appellate Body has not elaborated on the relative importance of the factors vis-à-vis each other. The question of importance is left open to be determined on a case-by-case basis. The risk with such an approach is that it may leave policymakers in a rather tricky position when constructing export controls, because factors that are deemed as essential domestically might not be perceived as such internationally.

\section{$4 \quad$ Linking Export Controls to Indirect Expropriation}

\subsection{Background}

FTAs and BITs have long included definitions that deal with the risks of nationalisation or expropriatory actions by host governments. Attitudes of arbitral tribunals have been consistent as far as the basic conceptualisation of expropriation is concerned. For example, in Amoco International Finance Corp $v$ Iran, it was held by the Iran - US Claims Tribunal that "[e]xpropriation, which can be defined as a compulsory transfer of property rights, may extend to any right which can be the object of a commercial transaction". ${ }^{25}$

Furthermore, the Iran - US Claims Tribunal noted in Phillips Petroleum Co Iran $v$ Iran that expropriation gives rise to liability for compensation regardless of "whether the expropriation is formal or de facto and whether the property is tangible, such real estate or a factory, or intangible, such as the contractual rights involved in the present case". ${ }^{26}$

Tribunals have also held that duty to compensate cannot be evaded by the host state on the grounds of any narrow meaning accorded to the term "expropriation" under municipal law. ${ }^{27}$

\footnotetext{
23 Ibid.

24 Ibid.

25 Amoco International Finance Corp v Iran (Partial Award No. 310-56-3) (1987) 15 Iran-US CTR 89, [108].

26 Phillips Petroleum Co Iran v Iran (Award No. 425-39-2) (1989) 21 Iran-US CTR 79, [76].

27 Southern Pacific Properties (Middle East) Ltdv Egypt (Award on the Merits) (ICSID Arbitral Tribunal, Case No ARB/84/3, 20 May 1992) [168].
} 
Indirect expropriation, however, has eluded a specific definition. Arbitral tribunals have often referred to the analysis of indirect expropriation as being driven by the facts of each claim. ${ }^{28}$ For example, in Amco Asia Corporation $v$ Indonesia, the withdrawal of investment authorisation by a government body was treated as an expropriation. ${ }^{29}$ In Southern Pacific Properties (Middle East) Limited $v$ Arab Republic of Egypt, the cancellation of a tourist development project in order to protect antiquities was considered to be an "unquestionable attribute of sovereignty" and hence unchallengeable because of public interest. ${ }^{30}$ However, the tribunal specifically stated that if expropriation is for a legitimate purpose, then it must be accompanied by fair compensation, otherwise it will amount to confiscation. ${ }^{31}$ The definition of indirect expropriation depends on "the specific facts and circumstances of the case, particularly the gravity and length of interference, the rights of the parties under a contract, or general legislation, and even cultural elements that define shared expectations". ${ }^{32}$ It is also noteworthy that expropriation and indirect expropriation are predicated on the fact that there must be a substantial deprivation of benefits or loss of value of investments as a result of governmental action.

In the oft-cited Metalclad $v$ Mexico dispute, the arbitral tribunal explained that expropriation may encompass "covert or incidental interference with the use of property" which may deprive the owner of "use or reasonablyto-be expected economic benefit of property". ${ }^{33}$ Similarly, some arbitral awards recognise restrictions on property rights, enhanced taxation, alteration of contractual rights or the suspension or withdrawal of licenses and/or regulatory permits as measures amounting to indirect expropriation. ${ }^{34}$ This, however, must be contrasted with the proposition that regulatory takings or expropriatory actions by states is justified, with or without compensation, if

28 Yvette Anthony, “The Evolution of Indirect Expropriation Clauses: Lessons from Singapore's BITs/FTAs" (2017) 7(2) Asian Journal of International Law 319, 325.

29 Amco Asia Corporation v Indonesia (Award) (1984) 1 ICSID Rep 413, [244]-[250].

30 Southern Pacific Properties (Middle East) Ltd v Egypt (Award on the Merits) (n 27) [58]-[129].

31 Ibid [163].

32 Francisco Vicuna, "Carlos Calvo, Honorary NAFTA Citizen" (2003) 11(1) New York University Environmental Law Journal 19, 28, cited by Anthony (n 27) 325.

33 Metalclad Corporation v Mexico (Award) (ICSID Arbitral Tribunal, Case No ARB(AF)/97/1, 30 August 2000) [103].

34 For example, in Compania del Desarrollo de Santa Elena SA v Costa Rica, the tribunal observed that lapse of time can be a relevant factor in determining whether expropriation has occurred. This may be of immediate effect (like an outright seizure) or through a series of interconnected measures that gradually amount to a loss of ownership: Compania del Desarrollo de Santa Elena SA v Costa Rica (Final Award) (ICSID Arbitral Tribunal, Case No ARB/96/1, 17 February 200o) [76]-[77]. In determining indirect expropriation, some 
the measures are taken in the "public interest" or pursuant to the "police powers" of a state. ${ }^{35}$ However, what amounts to "police powers" of a state may vary from country to country, according to their municipal systems.

According to analysis by Yvette Anthony, the "police powers" of the state and the exercise of powers for "public purpose" or in the "public interest" are two different concepts. ${ }^{36}$ Anthony cites awards in Chemtura, AWG and Too $v$ Greater Modesto Insurance Associates to stress that the exercise of "police powers" by the host state does not constitute expropriation. ${ }^{37}$ Anthony further observes that the US position on this issue is that a state is not responsible for any economic disadvantage incurred by the foreign investor that results from the exercise of the state's bona fide "police powers". Factors such as the discriminatory application of governmental measures, the extent of deprivation or loss of control over investment and the circumstances of each case may be considered when determining whether "police powers" degenerate into expropriation. Such factors are balanced with indicators such as the protection of public morality, public welfare, health and the environment to determine what constitutes "public interest", "public purpose" or "police powers". 38

Therefore, the question becomes, even where states are exercising legitimate "police powers" to achieve a "public welfare" aim or the preservation of the environment, whether the duty to compensate the foreign investor is then triggered or not. This is a question that continues to receive extensive academic attention but which exceeds the scope of this article. Suffice here to say that no clear answers have emerged from IsDs jurisprudence, and recourse is made

awards have indicated that the effect of state measures and the degree of loss suffered by foreign investor is the operative factor, rather than the intent behind the state measures: Anthony (n 28) 325; see also Fireman's Fund Insurance Company v Mexico (Award) (ICSID Arbitral Tribunal, Case No ARB(AF)/o2/1, 17 July 2006) [176(f)]. The tribunal in Spyridon Roussalis $v$ Romania declared that the effect of actions of the state is the key to determine whether indirect expropriation has occurred or not: Spyridon Roussalis $v$ Romania (Award) (ICsID Arbitral Tribunal, Case No ARB/o6/1, 7 December 2011) [327]-[328].

See, eg, the discussions in Andrew Newcombe and Lluis Paradell, Law and Practice of Investment Treaties: Standards of Treatment (Kluwer Law International, 2004) 341, 358; see also Anthony (n 28) 319, 327; James Crawford, Brownlie's Principles of Public International Law (Oxford University Press, 8th ed, 2008) 624; Surya Subedi, International Investment Law: Reconciling Policy and Principle (Hart Publishing, 2nd ed, 2012) 79, 119, 124.

36 Anthony (n 28) 332.

37 Chemtura Corporation v Canada (Award) (Permanent Court of Arbitration, Case No 200801, 2 August 2010) [266]; AWG Group v Argentina (Decision on Liability) (ICSID Arbitral Tribunal, Case No ARB/o3/19, 30 July 2010) [139]; Too v Greater Modesto Insurance Associates (1989) 23 Iran-US CTR 378.

38 Anthony (n 28) 332; see also American Law Institute, Restatement (Third) of Foreign Relations Law of the United States (1987) § $712 \mathrm{cmt}$ (g) ("Third Restatement"). 
to a case-by-case approach to determine the question of whether compensation is payable or not.

In addition to the "police powers" arguments, disputes such as Tecmed $v$ United Mexican States ${ }^{39}$ and others ${ }^{40}$ highlight the approach of "legitimate expectations" that foreign investors may have considered when making the decision to invest. ${ }^{41}$ The doctrine of legitimate expectations has gradually morphed

39 See generally Técnicas Medioambientales Tecmed SA v Mexico (Award) (ICSID Arbitral Tribunal, Case No ARB(AF)/oo/2, 29 May 2003) [154] (“Tecmed").

40 Other disputes following the Tecmed line of argument include LG\&E Energy Corp, LG\&E Capital Corp and LG\&E International Inc v Argentina (Decision on Liability) (ICSID Arbitral Tribunal, Case No ARB/o2/1, 3 October 2006) [127]; Occidental Exploration and Production Company v Ecuador (Final Award) (London Court of International Arbitration, Case No UN 3467, 1 July 2004) [185]; cMs Gas Transmission Company v Argentina (Award) (ICSID Arbitral Tribunal, Case No ARB/o1/08, 12 May 2005) [279]; Sempra Energy International v Argentina (Award) (ICSID Arbitral Tribunal, Case No ARB/02/16, 28 September 2007) [298]. The Tecmed standard is criticised by Zachary Douglas as an example of "perfect public regulation in a perfect world, ...which all states should aspire but very few (if any) will ever attain": Zachary Douglas, "Nothing if Not Critical for Investment Treaty Arbitration: Occidental, Eureko and Methanex" (2006) 22(1) Arbitration International 27, 28.

41 Academics have highlighted the varied nature of the concept of legitimate practice. For example, Michele Potesta highlights the utility of using legitimate expectations in situations where an investor is induced on the basis of informal representations by the host country: Michele Potesta, "Legitimate Expectations in Investment Treaty Law: Understanding the Roots and the Limits of a Controversial Concept" (2013) 28(1) ICSID Review 88, 103-110, 121-122. Christopher Campbell, however, is more critical of the concept and terms it as an "invention of arbitrators", stating, moreover, that arbitral tribunals are grounding their decisions by citing other arbitral awards that do not carry precedent value and, hence, the doctrine should be rejected as providing any basis on which to judge state conduct: Christopher Campbell, "House of Cards: The Relevance of Legitimate Expectations under Fair and Equitable Treatment Provisions in Investment Treaty Law" (2013) 30(4) Journal of International Arbitration 361, 378-379. Elizabeth Snodgrass, on the other hand, is more accepting of the doctrine. She argues that the doctrine of legitimate expectations should be recognised as a general principle of law on the basis of a comparative survey of various European Union jurisdictions: see Elizabeth Snodgrass, "Protecting Investors' Legitimate Expectations: Recognizing and Delimiting a General Principle" (2006) 21(1) ICSID Review - Foreign Investment Law Journal 1, 56-58. Christoph Schreuer and Ursula Kriebaum offer a more balanced view, arguing that not every expectation upon which a foreign investor makes a business decision can form the basis of an expropriation claim against foreign investor. Schreuer and Ursula point out that the application of the legitimate expectation's argument is quite situational, especially in complex transactions. In order for foreign investors to rely on legitimate expectations, the foreign investor must have knowledge and basis on which reasonable expectations can take a business decision. These bases can be grounded in general regulatory framework or through governmental assurances: see Christoph Schreuer and Ursula Kriebaum, "At What Time Must Legitimate Expectations Exist?" in Jacques Werner and Arif Hyder Ali (eds), A Liber Amicorum: Thomas Wälde. Law beyond Conventional Thought (CMP Publishing, 2009) 265, $269-270,273^{-276}$. 
from its initial beginnings as an obiter dictum in the Tecmed award. Within the larger framework of ISDS, the doctrine of legitimate expectations occupies an uneasy posture when juxtaposed with a host state's right to regulate in the public interest. The doctrine of legitimate expectation views the stability and predictability of the regulatory system as a function of the fair and equitable treatment to be accorded to the foreign investor. In doing so, the foreign investor may have a legitimate expectation that, during the subsistence of the investment, the domestic regulatory framework would not be altered or modified in any way. ${ }^{42}$

Clearly, the expectation by foreign investors that there will never be regulatory intervention or legislative reform is unrealistic and problematic. Indeed, this proposition has received some recognition, for example in Impregilo $v$ Argentina, where the dispute settlement tribunal stated that the legitimate expectations of foreign investors cannot be that the state will not modify its legislation. However, foreign investors are entitled to protection from unreasonable modifications of the legislative framework. ${ }^{43}$

Another aspect of the legitimate-expectations argument is that the government of the host state will be bound by any undertakings or representations given to the foreign investor prior to the foreign investment being made. ${ }^{44} \mathrm{In}$ Thunderbird $v$ Mexico, the tribunal tackled the question of legitimate expectations based on a legal opinion rendered by a governmental department. Interestingly, the tribunal held that legal advice cannot constitute the basis for legitimate expectations unless the foreign investor discloses the full and complete nature of the investment in advance. ${ }^{45}$ Even when the advice is of a more informal nature, tribunals have been cautious in classifying such

42 CMs Gas Transmission Company v Argentina (Award) (n 40) [274]-[276].

43 Impregilo SpAv Argentina (Award) (ICSID Arbitral Tribunal, Case No ARB/07/17, 21 June 2011) [291]-[292]; see further arguments in Potesta (n 41) 117.

44 See, eg, the discussion in Rudolf Dolzer and Christoph Schreuer, Principles of International Investment Law (Oxford University Press, 2nd ed, 2012) 148-149; see also Aniruddha Rajput and Sarthak Malhotra, "Legitimate Expectations in Investment Arbitration: A Comparative Perspective" in Mahendra Pal Singh and Niraj Kumar (eds), The Indian Yearbook of Comparative Law (Springer, 2018) 297, 302-303.

45 International Thunderbird Gaming Corporation v Mexico (Award) (North American Free Trade Agreement Chapter 11 Tribunal, 26 January 2006) [145], [147]-[148], [155], [166]. Thomas Wälde's separate opinion in the Thunderbird case highlights that the "quite high" threshold for assurances and specific representations can only be met if the assurances visibly display an official character: International Thunderbird Gaming Corporation v Mexico (Separate Opinion of Thomas Wälde) (North American Free Trade Agreement Chapter 11 Tribunal, 26 January 2006) [32]; See also Potesta,(n 41) 105-107. 
representations as specific enough to give rise to a breach the fair and equitable standards under the legitimate expectations argument. ${ }^{46}$

Disputes involving indirect expropriation have also received attention under the proportionality principle, which entails evaluating a range of possible regulatory measures and opting for the least intrusive course of action. ${ }^{47} \mathrm{Re}$ cent arbitral awards have also considered the interplay between proportionality and reasonableness. Detailed treatment of this issue, however, is beyond the scope of this article. Here, proportionality is being briefly discussed as an alternative approach to the sole effects or police powers doctrine.

Proportionality seeks to achieve a balance between the competing imperatives of governmental regulations and the commercial interests of foreign investors. It does so by posing four interlinked queries which must be satisfied:(i) the measure must be seen to achieve a legitimate aim; (ii) the measure must be suitable to the achieve that aim; (iii) the test of necessity must be applied; ${ }^{48}$ and (iv) the measure must be balanced against competing interests,

$46 \quad$ This is seen in the high profile Metalclad case as well as in White Industries $v$ India, where a governmental official made a statement describing the Australian and Indian legal systems as similar. The tribunal termed such a statement as too broad and non-specific to trigger legitimate expectations: White Industries Australia Limited v The Republic of India (Final Award), (Ad Hoc Tribunal under the Uncitral Arbitration Rules, 30 November 2011) [5.2.6], [10.3.17].

47 See, eg, Caroline Henckels, Proportionality and Deference in Investor-State Arbitration (Cambridge University Press, 2015) 23-26; see also Caroline Henckels, "Indirect Expropriation and the Right to Regulate: Revisiting Proportionality Analysis and the Standard of Review in Investor-State Arbitration" (2012) 15(1) Journal of International Economic Law 223, 224-228; see also Benedict Kingsbury and Stephen W Schill, "Public Law Concepts to Balance Investors' Rights with State Regulatory Actions in the Public Interest: The Concept of Proportionality" in Stephen W Schill (ed), International Investment Law and Comparative Public Law (Oxford University Press, 2010) 75, 77-88.

48 The "necessity" test under the proportionality principle has a peculiar overlap with the equivalent term in wто jurisprudence. Mitchell and Henckels consider the necessity analysis conducted by the arbitral tribunals to be more fragmented than the што jurisprudence on the area. One particularly relevant argument by Mitchell and Henckels is that што jurisprudence provides a useful source for guiding investment tribunals in determining necessity because WTO panels have displayed appropriate institutional sensitivity and deference to national autonomy in their analysis: Andrew Mitchell and Caroline Henckels, "Variations on a Theme: Comparing the Concept of "Necessity" in International Investment Law and wто Law" (2013) 14(1) Chicago Journal of International Law 93, 126-137, 160,163; see also Mads Andenas and Stefan Zlepting, "Proportionality: WTo Law in Comparative Perspective" (2007) 42(3) Texas International Law Journal, 371, 383 . 
by weighing and balancing the social importance of achieving the measure's aims against the social importance of harm avoidance. ${ }^{49}$

Similar to the doctrine of legitimate expectations, arbitral practice shows a mixed usage of the proportionality principle. For example, Saluka v Czech Republic shows an early attempt to use proportionality in order to explain the failure by the Czech Republic to extend fair and equitable treatment to foreign investment by the claimant (Saluka). ${ }^{50}$ On closer inspection, the Saluka award seems more in the line of "police powers" rather than setting a new standard. ${ }^{51}$ The Saluka rule is succinctly summarised by Prabhash Ranjan as providing that "a bona fide, non-discriminatory measure adopted for public welfare objective is not expropriation, notwithstanding the economic impact on foreign investment". ${ }^{52}$

The proportionality doctrine, in terms of the lawfulness of a state action, received more attention in the American Silver $v$ Bolivia dispute, which concerned a Bolivian governmental action of ordering the revocation of mining licences and the reversion of land ownership to the land's indigenous owners. ${ }^{53}$ The tribunal explained that, contrary to the assertion by the claimant (American Silver), social benefit cannot be equated with purely economic benefit, seen through the lens of the expected economic benefit for the local communities, while ignoring the surrounding political and socio-economic situation in the region. ${ }^{54}$

The tribunal also interpreted the strict proportionality standard and stipulated that the economic loss for the investor cannot have more weight than the protection of the interests of the indigenous people. ${ }^{55}$ For the tribunal in the

49 See, eg, a summary of the proportionality approach in Henckels, Proportionality and Deference in Investor-State Arbitration (n 47) 24-26; see also Aharon Barak, Proportionality (Cambridge University Press, 2012) 131, 357, 484.

50 Saluka Investments BVv Czech Republic (Partial Award) (Ad Hoc Tribunal under the UNCITRAL Arbitration Rules, 17 March 2006); see further discussion in George S Georgiev, "The Award in Saluka Investments v Czech Republic" in Guillermo Aguilar Alvarez and W Michael Reisman (eds), The Reasons Requirement in International Investment Arbitration (Nijhoff, 2008) 149, 15 o.

51 Prabhash Ranjan, "Police Powers, Indirect Expropriation in International Investment Law, and Article 31(3)(c) of the vCLT: A Critique of Philip Morris v Uruguay" (2019) 9(1) Asian Journal of International Law 98, 114-115.

52 Ibid 115 .

53 South American Silver Ltd v Bolivia (Award) (Permanent Court of Arbitration, Case No 2013-15, 22 November 2018) [169]; see also the discussion in Lasse Langfeldt, "Proportionality in Investment Treaty Arbitration and the Necessity for Tribunals to Adopt a Clear Methodology" (LLM Thesis, Uppsala University, 2019) 24-26.

54 South American Silver Ltd v Bolivia (Award) (n 53) [578].

55 Ibid [578]. 
American Silver dispute, the initial point of investigation for the purposes of meeting the proportionality standard was to investigate whether the FTA or BIT that drove the investment (in this case, the United Kingdom-Bolivia BIT) ${ }^{56}$ mentioned the proportionality standard or not. In this dispute, the United Kingdom-Bolivia BIT did not specifically address the standard of a proportionate response in relation to expropriation. ${ }^{57}$ In fact, the very reason that the tribunal discussed proportionality was because the parties addressed the reversion as an issue from the perspective of proportionality. ${ }^{58}$ In RREE F $v$ Spain, the tribunal considered proportionality as being closely connected to reasonableness, ${ }^{59}$ which is somewhat distinct from the earlier Tecmed characterisation of a regulatory measure as not being expropriatory where a reasonable relationship of proportionality can be established between the burden imposed by regulatory measures on foreign investors and the aims that the challenged measures are designed to achieve. ${ }^{60}$ Regardless of the approaches and arbitral practices which have developed for explaining direct and indirect expropriation, the older generation of BITs and FTAs were more circumspect about the question of expropriation. Such BITs and FTAs included broadly worded provisions which mentioned the duty of prompt and adequate compensation but did not include specific mechanisms in the texts. Prominent examples include the North American Free Trade Agreement ("NAFTA") art 1110, ${ }^{61}$ the AustraliaThailand FTA art 912, ${ }^{62}$ the Indonesia-Thailand BIT art VI ${ }^{63}$ and the SingaporeChina BIT art $6 .{ }^{64}$

56 Agreement between the Government of the United Kingdom of Great Britain and Northern Ireland and the Government of the Republic of Bolivia for the Promotion and Protection of Investments, signed 24 May 1988, [1990] U KTS 34 (entered into force 16 February 1990).

57 South American Silver Ltd v Bolivia (Award) (n 53) [570].

$5^{8}$ See Langfeldt (n 53$) 26$.

59 RRE F F Instructure Ltd and RRE E F Pan-European Infrastructure Two Lux Sàrlv Spain (Decision on Responsibility and on the Principles of Quantum) (ICSID Arbitral Tribunal, Case No $\mathrm{ARB} / 13 / 30,30$ December 2018) [463]-[468].

6o See Tecmed (n 39) [121]-[122]; see also the discussion in Ranjan (above n 51) 116.

61 See North American Free Trade Agreement, Canada-Mexico-United States, signed 17 December 1992, 32 ILM 289 (entered into force 1 January 1994).

62 See Australia-Thailand Free Trade Agreement, signed 5 July 2004, [2005] ATs 2 (entered into force 1 January 2005).

63 See Agreement between the Government of the Republic of Indonesia and the Government of the Kingdom of Thailand for the Promotion and Protection of Investments, signed 17 February 1998 (entered into force 5 November 1998).

64 See Agreement on the Promotion and Protection of Investments (with Exchange of Letters), China-Singapore, signed 21 November 1985 (entered into force 7 February 1986). 
The newer generation of FTAs and BITs now prescribe detailed expropriation provisions, including "carve outs", which expressly exclude public welfare objectives from the competence of the arbitral tribunals examining expropriation claims. Some examples of such provisions in the "new wave" of FTAS and BIT s that include greater details and specificity are the ASEAN Comprehensive Investment Agreement ("ACIA") annex $2,{ }^{65}$ the Comprehensive and Progressive Trans-Pacific Partnership ("СPTPP") annexes 9-B and 9-C,66 the CanadaEuropean Union ("EU") Comprehensive and Economic Trade Agreement ("CETA") art 8.12, ${ }^{67}$ the EU-Vietnam Investment Protection Agreement art 2.7 and the accompanying Annex 4 (Understanding on Expropriation). ${ }^{68}$ These new wave FTAs and BITs contain greater details instructing future arbitral panels (or in case of CETA and the EU-Vietnam FTA, the newly constituted bilateral investment courts) on the factors which cause government conduct to amount to a legitimate exercise of governmental "police powers". In doing so, countries are eliminating the possibility of arbitral tribunals introducing their own interpretations in the dispute. However, even in the new wave FTAs and BITs, the concepts of "public purpose" and "legitimate public policy" are neither clarified nor defined. Hence, challenges by foreign investors can be mounted against state measures by questioning their legitimacy.

\subsection{Underlying Assumptions: Can Export Controls by a Host State Amount to Indirect Expropriation?}

Certain assumptions will be made for the purposes of the subject query. These are necessary to connect two otherwise unrelated concepts (export control is a trade measure, whereas indirect expropriation is an investment concept). However, both concepts spring from governmental action. The assumptions are summarised hereinbelow:

Assumption 1: An investment being expropriated is controlled by a foreign investor and is made under an existing FTA or bit;

Assumption 2: The main aim behind an investment is the processing and export of certain product(s). The services sector is excluded. Exports constitute a major share of the revenue of the investor;

65 See ASEAN Comprehensive Investment Agreement, signed 26 February 2009 (entered into force 24 February 2012) ("ACIA").

66 See Comprehensive and Progressive Agreement for Trans-Pacific Partnership, signed 8 March 2018, [2018] ATS 23 (entered into force 30 December 2018).

67 Comprehensive Economic and Trade Agreement, signed 30 October 2016 (not yet in force).

68 EU - Vietnam Investment Protection Agreement, signed 30 June 2019 (not yet in force). 
Assumption 3: Export controls are imposed pursuant to a governmental policy and cause revenue-based damages to the foreign investor, due to the price difference between domestic and international sales; and

Assumption 4: Export controls are applied across the board and affect local and foreign-owned businesses equally. Therefore, violation of national treatment ("NT") norms is not at issue.

\subsection{Simulated Scenarios}

An overlap between the GATT art Xx exceptions and the commonly cited public welfare and environmental grounds is immediately apparent. One particularly relevant exception, discussed above, is GATT $\operatorname{art} \mathrm{xx}(\mathrm{j})$, pursuant to which a WTO member can adopt measures restricting exports in order to alleviate "general or local short supply". Using GATT $\operatorname{art} \mathrm{xx}(\mathrm{j})$, and the assumptions outlined above, the following simulated scenarios are constructed to explain the proposition that export controls may amount to indirect expropriation.

The first scenario is based on Country $\mathrm{X}$, a resource-based economy with a shrinking manufacturing base, that attracts foreign direct investment into the resources sector. The government of Country $\mathrm{X}$ grants concessions and tax breaks for foreign investors who wish to engage in development and exploration in the natural resource sector. In one case, Corporation A (a large, multinational gas company owned by foreign investors based in a BIT state party) heavily invests in the exploration for, and refining of, natural gas in Country X. Corporation A's business strategy is to export the bulk of output to Asia, where there is high demand for gas. Country $\mathrm{X}$ is facing high domestic energy prices. The prices in the Asian export markets, however, are lower than the price in Country X. The government of Country X notices the price differential and sees establishment of new gas-fired power plants as the solution for securing energy needs and bringing down the domestic price of gas. Accordingly, Country X systematically imposes export controls on gas to increase domestic supply. Country X justifies the new policies on the grounds of energy security, price stabilisation, the rights of people over their own resources, social license and acting in the larger public interest. The export controls are introduced in the form of quotas, which results in a reduction in the volume of refined gas that Corporation A can export. Resultantly, Corporation A's projected revenue decreases for the duration of export controls, while this news further affects the stocks of Corporation A. Has Country X indirectly expropriated Corporation A's investment through its export controls?

The second scenario is based on Country Y, a highly populated, developing country that is increasingly penetrating the developed markets with its 
cheaply-produced consumer goods. Country Y launches an ambitious plan to advance its manufacturing sectors and create additional job opportunities within the economy. The government imposes a five-year export control over certain raw materials and rare earths. The plan is to inwardly divert raw materials for use in the domestic manufacturing of value-added products for export. The export controls come in the form of increased tariffs added to the free-onboard ("FОв") price. The increased tariffs will be phased out over a five-year period. Resultantly, the export prices of rare earths increase, which consequently affects the price in the world market as well. In one case, Corporation B (an international mining business, incorporated as a company under the laws of Country $\mathrm{Y}$ ) is engaged in mining and processing rare earths, which are exported in the form of ingots to specialised businesses overseas. Corporation B has invested in significant infrastructure for mining, processing and exporting rare earths. The measures by Country Y are forcing Corporation B to reduce its exports and divert its sales into the domestic market. Corporation B is further prevented from pursuing additional supply opportunities due to export controls. Corporation B believes that supplying domestic industries is not lucrative enough in the long run, and that the loss of additional business opportunities overseas has seriously affected the revenues of the business. Has Country Y indirectly expropriated Corporation B's investment through its export controls?

The third scenario is a deliberately constructed situation involving a mix of regulatory intervention and confiscatory actions. In this scenario, the government of Country Z, a least developed country ("LDC") that is a venue for outward production processing ("OPP”)-based investment by overseas apparel companies, exceeds the scope of proportionality and necessity while purportedly acting in the public interest. The OPP businesses working in Country Z engage a vast number of employees in order to export their finished apparel. The export-oriented commercial and manufacturing activity is a valuable source of revenue for Country Z's economy. The apparel and textiles businesses in Country Z often source cotton yarn from domestic cotton yarn manufacturers, who in turn rely on cotton growers in Country $\mathrm{Z}$ to supply them with raw cotton. The cotton yarn manufacturers primarily supply their products domestically and any surplus is exported. Due to a sudden and unforeseen shortage of cotton yarn internationally, cotton yarn manufacturers see a spike in demand from overseas buyers and begin exporting yarn to maximise their profits, leading to domestic yarn shortages which affect local apparel manufacturing. Several delivery orders are delayed or cancelled because the manufacturers were unable to source cotton yarn domestically. The representative association of apparel manufacturers approach the government of Country $\mathrm{Z}$ and demand that export controls be imposed on cotton yarn manufacturers. The cotton 
yarn manufacturers resist these demands. The crisis spirals out of control and results in rioting and protests. In one instance, a mob burns a warehouse owned by Corporation C (a company registered under the laws of Country Z, but with a majority shares owned by foreign shareholders through a local holding company). Corporation $\mathrm{C}$ runs a vertically integrated operation, which involves feeding cotton yarn into its textiles and apparel facilities. The final outputs are then exported as value-added items. Under increasing pressure from the apparel industries and labour unions, the government of Country Z imposes export controls on cotton yarn until domestic supplies are stabilised. The government further confiscates all cotton yarn in port warehouses that is destined for exports. Corporation $\mathrm{C}$ feels aggrieved by the actions of Country Z and the foreign investors (the shareholders of Corporation $\mathrm{C}$ ) view this action as expropriatory. Has Country C indirectly expropriated Corporation C's investment through its export controls and confiscatory actions?

With the above simulations summarising the basic positions of the imposing countries, potential arguments on export controls qualifying as indirect expropriation will now be discussed.

\subsection{Arguments}

The simulated scenarios illustrate instances where government actions have affected foreign investors' ability to export and earn profits. The decision to control exports can either be classified under the broader category of "police powers" of the state or actions taken in the "public interest" or for "public welfare". Alternatively, the expropriatory actions can be viewed through the lens of proportionality or the legitimate expectations of the foreign investor. The classification is important because the result may alter the outcome of the ISDS process, and may well affect the terms of compensation available to the foreign investors. Also, the expressions "police powers", "public interest" and "public welfare" have no universally accepted legal definition. Therefore, the only indicators are treatment of the issue under the principles of customary international law, in academic literature and/or by various arbitral tribunals constituted under FTAs and BITs.

The question of indirect expropriation and its difference from noncompensable taking under an exercise of "police powers" of the state is equally important to both foreign investors and governments. According to Dolzer and Stevens, for the foreign investor: ${ }^{69}$

69 Rudolf Dolzer and Margrete Stevens, Bilateral Investment Treaties (Martinus Nijhoff Publishers, 1995) 98, quoted in Organisation on Economic Co-operation and Development, "Indirect Expropriation' and the 'Right to Regulate' in International Investment Law" (Working Paper on International Investment No 2004/04, September 2004) 5 . 
$[\mathrm{t}]$ he line of demarcation between measures for which no compensation is due and actions qualifying as indirect expropriations (that require compensation) may well make the difference between the burden to operate (or abandon) a non-profitable enterprise and the right to receive full compensation (either from the host State or from an insurance contract). For the host State, the definition determines the scope of the State's power to enact legislation that regulates the rights and obligations of owners in instances where compensation may fall due.

Sornarajah considers that governmental measures related to "anti-trust, consumer protection, securities, environmental protection, land planning are non-compensable takings since they are regarded as essential to the efficient functioning of the state. ${ }^{70}$ However, any powers of the state that are exercised must be non-discriminatory. ${ }^{71}$ Arbitral awards such as Chemtura Corporation $v$ Government of Canada hold that the exercise of states' police powers must be linked to imperatives such as the protection of human health and the environment. ${ }^{72}$ In Saur International SA v Argentina, the tribunal stipulated that in certain situations, the legitimate exercise of police powers of the state does not give rise to an obligation to compensate. ${ }^{73}$

Adding to the problem of legitimacy is the fact that any state can view its actions in the public realm as "necessary" to achieve a stated public purpose. The problem of necessity featured in several wTo cases such as Korea-Beef, ${ }^{74}$

70 Muthucumaraswamy Sornarajah, The International Law on Foreign Investment (Cambridge University Press, 1994) 283, cited in ibid 4-5.

71 See, eg, Robert Jennings and Arthur Watts (eds), Oppenheim's International Law (Oxford University Press, 9th ed, 1992) 919-920; BP Exploration Company (Libya) Ltd v Libya (1973) 53 ILR 297, 329 ("BP Exploration"); Methanex Corporation v United States (Final Award on Jurisdiction and Merits) (2005) 44 ILM 1345, 1456 ("Methanex (Final Award)"); Veijo Heiskanen, "The Contribution of the Iran-United States Claims Tribunal to the Development of the Doctrine of Indirect Expropriation" (2003) 5(3) International Law Forum 176, 179, 185; Ben Mostafa, "The Sole Effects Doctrine, Police Powers and Indirect Expropriation under International Law" (2008) 15(15) Australian International Law Journal 265, 272-274.

72 Chemtura Corporation v Canada (Award) (Permanent Court of Arbitration, Case No 200801, 2 August 2010) [266], cited in Anthony (n 28) 329.

73 SAUR International SA v Argentina (Decision on Jurisdiction and Liability) (ICSID Arbitral Tribunal, Case No ARB/04/4, 6 June 2012) [398], cited in Anthony (n 28) 329.

74 Appellate Body Report, Korea - Measures Affecting Imports of Fresh, Chilled and Frozen Beef, wTo Doc WT/DS161/AB/R;WT/DS169/AB/R (11 December 20oo) ("Korea-Beef, Appellate Body Report"). In Korea - Beef, the Appellate Body held that the term "necessary", within the meaning of GATT art $\mathrm{xx}(\mathrm{d})$, requires a weighing and balancing of several factors which include the contribution of the compliance measure in enforcement of the law in question, the importance of common interests or values protected by the law and the impact of law on "imports or exports": at [164]. 
EC - Asbestos, ${ }^{75}$ EC - Tariff Preferences,${ }^{76}$ US - Gambling ${ }^{77}$ and Brazil Retreaded Tyres. ${ }^{78}$ In Brazil - Retreaded Tyres, for example, the Appellate Body

75 Appellate Body Report, European Communities - Measures Affecting Asbestos and Asbestos-Containing Products, wTo Doc WT/DS135/AB/R (12 March 2001) ("EC - Asbestos, Appellate Body Report"). In $E C$ - Asbestos, the Appellate Body analysed the interpretation of "reasonably available" alternatives in order to determine whether French import restrictions were "necessary" within the meaning of GATT art xx(b): at [170], [173]-[175].

76 Appellate Body Report, European Communities - Conditions for the Granting of Tariff Preferences to Developing Countries, wTo Doc WT/DS246/AB/R (7 April 2004) ("EC - Tariff Preferences, Appellate Body Report"); Panel Report, European Communities - Conditions for the Granting of Tariff Preferences to Developing Countries, wTo Doc WT/DS246/R (1 December 2003) ("EC - Tariff Preferences, Panel Report"). The EC - Tariff Preferences case demonstrates that interpretation of "necessary" must be coupled with proven "effectiveness" of the trade measures (in this case, the EU's European Generalised System of Preferences ("GSP") scheme). The EU justified the scheme on the grounds that GSP tariff preferences promoted the "development of alternative economic activities to replace illicit drug production and trafficking" which, therefore, satisfied the standard under GATT $\operatorname{art} \mathrm{xx}(\mathrm{b})$. The dispute settlement panel disagreed, and stated that the scheme was developmental in nature, with an emphasis on promotion of sustainable development in developing countries, which would mean that EU's defence under GATT $\operatorname{art} \mathrm{xx}(\mathrm{b})$ was invalid. The panel cited the declining utility of GSP schemes due to global tariff reduction under WTO obligations, along with a lack of monitoring and compliance mechanisms for measuring "effectiveness" of the GSP scheme and the availability of less trade restrictive options. The panel concluded that the part of the EC GSP schemes relating to drug arrangements was not "necessary" to protect human life or health: [4.92]-[4.99], [7.211], [7.219] -[7.223]. The valuable takeaway for policymakers from the $E C$ - Tariff Preferences case is that if a country adopts export controls and then seeks to justify them under the "necessary" standard, the measures must be factually proven as effective to achieve the stated goals.

77 The case concerned Marrakesh Agreement Establishing the World Trade Organization opened for signature 15 April 1994, 1867 UNTS 3 (entered into force 1995) annex B ("General Agreement on Trade in Services") art XIV(a), which is identically worded to GATT art $\mathrm{xx}(\mathrm{a})$. The meaning of the term "necessary" was pinned to earlier jurisprudence (ie, assessing the "relative importance" of the interests or values promoted by the challenged measure, contribution of the measure to the achievement of the aims pursued by it, restrictive impact of the measure on international trade, weighed and measured with the interests or values, and, finally, a comparison between the challenged measure and possible alternatives available): Appellate Body Report, United States - Measures Affecting the Cross-Border Supply of Gambling and Betting Services, wTo Doc WT/DS285/AB/R (7 April 2005) [291], [304]-[309] (“US - Gambling, Appellate Body Report"). The Appellate Body also noted that "it is not the responding party's burden to show ... that there are no reasonably available alternatives to achieve its objectives" and that "a responding party need not identify the universe of less trade-restrictive alternative measures and then show that none of those measures achieves the desired objective": at [309]. Instead, the responding party must make a case that its measures are "necessary" by adducing evidence that allow the dispute settlement panels to assess the challenged measure in the light of the relevant factors to be "weighed and balanced" in a case: at [310]-[311].

78 Appellate Body Report, Brazil - Measures Affecting Imports of Retreaded Tyres, wTo Doc WT/DS332/AB/R (3 December 2007) (“Brazil - Retreaded Tyres, Appellate Body Report"); 
recognized the fundamental principle that WTO members have the right to determine the level of protection necessary to achieve a public policy goal. ${ }^{79}$ In the first scenario (discussed above), the government of Country X can justify its measures as "necessary" under GATT art $\mathrm{Xx}(\mathrm{d})$ by pointing to a short supply of gas which is leading to high energy prices within the country. To do so effectively, the challenge for Country $\mathrm{X}$ is to construct the export controls under the Korea - Beef approach by considering the possible alternatives which are reasonably available and then to further ensure that the "effectiveness" criteria is met, as highlighted in the EC - Tariff Preferences case.

Alternatively, Country X can consider pursuing an argument under GATT art $\mathrm{xx}(\mathrm{j})$, by claiming that export controls are "essential" to the distribution of products in "general or local short supply". To do so, the government of Country X must consider two factors: firstly, the "essential" criterion, and then the meaning of the term "general or local short supply" in the India - Solar Cells case. ${ }^{80}$ In determining the meaning of "essential", the Appellate Body in IndiaSolar Cells endorsed a test similar to the "necessary" test under GATT art Xx(d)

Panel Report, Brazil - Measures Affecting Imports of Retreaded Tyres, wTo Doc WT/DS 332 / AB/R (12 June 2007) ("Brazil - Retreaded Tyres, Panel Report").

79 The term "necessary" received further treatment in Brazil - Retreaded Tyres, where the subject was Brazil's ban and penalties on the import and marketing of, and dealing with, retreaded tyres. Brazil's regional trading partners in the Mercosur regime received exemptions. Brazil cited the "necessary" argument under GATT art $\mathrm{xx}(\mathrm{b})$ and (d). The case illustrates an acknowledgment by the wто that wTо Members have the right to determine the appropriate level of protection as per their public policy. The Appellate Body endorsed the panel's finding that the import ban on retreaded tyres can be provisionally justified:Brazil - Retreaded Tyres, Appellate Body Report (n 78), [145]. The panel "weighed and balanced" the contribution of the import restrictions in the context of the stated objective of the Brazilian policy. The panel then considered alternatives suggested by the complainant, and held that the suggested measures did not constitute "reasonably available" alternatives to the import restrictions: Brazil - Retreaded Tyres, Appellate Body Report (n 78), [157]; See also Brazil-Retreaded Tyres, Panel Report (n 78) [7.159]. The Appellate Body further noted that even where the contribution of the measures is not immediately observable, the measure could still be considered "necessary" encourages policymakers to closely scrutinise factors that contribute to the overall objective of the trade restrictive measure: Brazil - Retreaded Tyres, Appellate Body Report (n 78), [210][212]. The WTO seems to be endorsing a position where the expectation is that the imposing Member has undertaken a comparative analysis of the measure in light of possible, less-trade restrictive alternatives, while at the same time, the complaining WTO Member, is afforded the opportunity to identify possible less-trade restrictive measures that the responding Member could have taken.

8o The term "essential", according to the Appellate Body, ranks closer to the "indispensable" end of the continuum than the word "necessary": India - Solar Cells, Appellate Body Report (n 7) [5.62]. 
which involves "weighing and balancing" a series of factors. ${ }^{81}$ Secondly, Country X must consider the meaning of the term "general or local short supply" as enunciated by the Appellate Body in India - Solar Cells. The Appellate Body stated that in settling the question of "general or local short supply", regard must be given to: 82

[t] he total quantity of imports that may be available to meet demand in a particular geographical area or market. It may ... be relevant to consider the extent to which international supply of a product is stable and accessible, including ... distance between a particular geographical area or market and production sites, as well as reliability of local or transnational supply chains. Whether and which factors are relevant necessarily depend on the particularities of each case.

The Appellate Body held that, regardless of the occurrence of factors in each case, the responding party (namely, the party imposing the export control) has the burden to demonstrate that the quantity of available supply, from both domestic and international sources, to the relevant geographical market is insufficient to meet demand. 83

No country has so far faced an accusation of expropriation in relation to export controls. If policymakers in a developing country design an investment policy, considerations that have been highlighted in India - Solar Cells provide a workable template in dealing with any future "general or local short supply" issue. Looking ahead, if these considerations are satisfied, a host country can adopt a "police powers"-based approach to argue that export controls are not expropriatory in nature and that the government had acted to alleviate "general or local short supply".

Indirect expropriation is usually connected to imperatives such as health and the environment. Devaluing the investment of a foreign investor(s) is often a by-product of governmental measures, which then leads to a claim of indirect expropriation by the affected foreign investor(s). Therefore, for Country $\mathrm{X}$, the challenges in constructing export controls is to not only satisfy the GATT obligations owed to other countries (where importers are based), but also to ensure that any investor who may be damaged by export controls is unable to lodge a claim under any BIT or FTA signed by Country X. Hence, the origin of the foreign investor is an important factor to consider before imposing

\footnotetext{
$81 \quad$ Ibid [5.63] (emphasis added).

82 Ibid [6.4].

83 Ibid.
} 
the export control. For example, assuming that Country $\mathrm{X}$ is already in a BIT with another country (Country D) and that investors (Corporation A) based in Country D have invested in the gas sector of Country $\mathrm{X}$ with the aim of extracting, refining and exporting gas from Country $\mathrm{X}$, then any measures that restrict the Corporation A's stated rationale for investment can become the basis of a claim against Country $\mathrm{X}$ for indirect expropriation. Country $\mathrm{X}$ may be liable to pay compensation to Corporation $\mathrm{A}$, however, this finding depends on a series of inter-connected factors such as legitimate expectations, the terms of the BIT, the proportionality and necessity of the adopted measures, and how the expropriation clauses are constructed within the underlying BIT. In any ISDS setting, Country X will most likely demonstrate that actions were undertaken pursuant to the police powers of the state, in order to ensure stable gas supply in the country, while Corporation A's strategy will be to claim compensation for indirect expropriation due to lost revenue and loss of share value. Alternatively, the government of Country X will seek to adopt an argument based in the proportionality, legitimacy and necessity analysis highlighted in more recent disputes such as RRE EF $v$ Spain and American Silver. ${ }^{84}$

One argument which may work in the favour of Country $\mathrm{X}$ is that if products are considered in "general or local short supply" under GATT $\operatorname{art} \mathrm{xx}(\mathrm{j})$, then this automatically boosts the public interest argument which, by implication, can settle the issue of the police powers of the state as well. In simpler terms, states have the right to ensure that their people have access to the basic resources needed for living (such as access to food, water, affordable energy and security, etc). Resultantly, the claim by Corporation A of indirect expropriation based on export controls may stand on a weak basis.

In the case of Country Y (the second scenario discussed above), the outcome might be somewhat different. In this scenario, export controls are being used by the government of Country Y to boost economic activity in the country by diverting critical materials inwards through prohibiting their export. Like the first scenario, Country Y may face allegations of indirect expropriation if the wording of any underlying FTA or BIT enables Corporation B (the investor) to initiate ISDS proceedings. For this to happen, Corporation B must demonstrate that it is owned, in terms of shares, by a party and/or shareholder based in an FTA or BIT partner country. However, where Corporation B has an advantage, where claims are concerned, is that powers exercised by the government of Country Y are not likely to be interpreted as police powers of the state or regulatory powers exercised in the public interest or for public welfare.

84 In this respect, see the arguments above 4.2. 
One can make the argument that governments have the right to adopt economic initiatives that result in economic advancement and the creation of jobs, but this argument may be on weak footing when it comes to the prejudice suffered by the foreign investor. Hence, Corporation B, in the second scenario, will have a stronger claim against Country Y for indirect expropriation. But what if Corporation B's investment was not under any FTA or BIT that Country Y has signed? In such a situation, Corporation B's efforts to protect its investment under an FTA or BIT will be difficult. ${ }^{85}$ From the experience of Phillip Morris's claim against Australia's tobacco plain-packaging regulations, any post facto restructuring in order to bring an expropriation claim will likely not succeed. ${ }^{86}$ Therefore, as long as Country Y treats investment in a non-discriminatory manner between domestic and foreign investors in the rare earths sector, it may be able to evade a claim of expropriation under any FTA or BIT.

One of the common themes in the first and second scenarios is that they both concern natural resources (gas and rare earths). In the second scenario, the changes introduced by Country $\mathrm{Y}$ are driven largely by economic and political motivations, whereas in the first scenario, the governmental measures are driven by a concern for ensuring stable gas supply. Both scenarios, however, hamper the ability of the foreign investors in question to carry out their business activity. A pre-emptive solution to the problem may be the incorporation of an economic equilibrium clause into the project agreement. ${ }^{87}$ The economic equilibrium clause enables stabilisation of the economic return to the investor, instead of stabilisation of the legal framework. ${ }^{88}$ Under economic equilibrium clauses, host states may be entitled to issue changes that can potentially affect the project, but will be bound to consult the foreign investor in order to

85 Russell Thirgood, Michael Roche and Erika Williams, "Australia: Proposed Lng Export Restraints and Australian Liability Under International Trade Law", mondaq (Web Page, 20 June 2017) <http://www.mondaq.com/australia/x/603326/Inward+Foreign+Invest ment/Proposed+LNG+export+restrictions+and+Australian+liability+under+internation al+trade+law>.

86 Phillip Morris attempted to restructure its investment in Australia to take advantage of the BIT between Hong Kong and Australia. This was ultimately unsuccessful and held to be an abuse of process by the tribunal: ibid.

87 For a brief discussion of the "economic equilibrium clause", see David Clinch and James Watson, "Stabilisation Clauses: Issues and Trends", Lexology (Web Page, 30 June 2010) <https://www.lexology.com/library/detail.aspx?g=c5976193-1acd-4o82-b9e7-87co $414 b_{5328}$.

88 Stabilisation clauses are contractual protections incorporated within long term investments between foreign investors and states. Majority of stabilisation clauses appear in investment agreements in the oil, gas and resources sector. They can also be found in infrastructure and transport projects as well: ibid. 
determine the impact of the proposed changes. ${ }^{89}$ The parties usually discuss a renegotiated framework of investment or, alternatively, the state will pay appropriate compensation to the foreign investor. Moreover, any ISDS proceedings will be subject to the host states discussing the governmental measures with the foreign investors if an economic equilibrium clause has been included in the investment framework. However, if parties disagree on the remedial measures or the compensation payable, then the foreign investors can weigh in on whether to claim indirect expropriation by initiating IsDS proceedings. The feasibility of negotiating economic equilibrium clauses by the foreign investor may be influenced by a variety of factors, which include but are not limited to: the appetite of the government of the host country to enter into pre-investment negotiations; the quantum and nature of foreign investments; the size and frequency of profit remittance from the host country; the sociopolitical sensitivity of the sector in which the foreign investor has invested; and the investor's own understanding of the regulatory standards in the host economy as well as under the FTA or BIT umbrella.

In contrast to the first two scenarios, the third scenario has been deliberately constructed to explain a situation where the conduct of the host country is composite of direct takings (confiscation), accompanied by export controls that make the export of goods unattractive. Confiscation is a clear instance of direct expropriation, but export controls, as argued above in the first and second scenarios, may only be found to constitute indirect expropriation provided that certain conditions are met. This may involve the foreign investor showing that the exercise of power by the state did not meet the reasonableness standard, which in turn, may involve considering factors such as the legitimacy of the state measure's purpose, its proportionality and necessity, and the suitability of the measure to achieve public welfare.

In the third scenario, a government imposes export controls due to pressure from interest groups. The governmental motives are a mixture of factors ranging from unforeseen developments in the international market, economic factors and its responsibility to maintain employment levels in the country. However, not all of the aforementioned factors can become grounds for defence against a claim for indirect expropriation. For example, in the first and second scenarios, exercising police powers or acting in the public welfare can give the host state an excuse to resist indirect expropriation claims by foreign investors. In the third scenario, the confiscatory action was aimed at placating labour unions and local apparel businesses, which is clearly not a public welfare

89 Ibid. 
objective. However, there may be a way out for Country Z. It is common knowledge that for many developing countries and LDCs, textiles and clothing are often the main value-added industries in their economy. If Country $\mathrm{Z}$ can satisfy the art $\mathrm{xx}(\mathrm{j})$ standard, it can basically argue that it is acting to alleviate "general or local short supply" in the country. If the measures are adopted in a non-discriminatory manner and are applied uniformly to all locally- and foreign-owned businesses, then there can be little doubt that such powers are part of the police powers of the state, which makes it difficult for the foreign investor to claim compensation.

Thus, can it be said that the government of Country $\mathrm{Z}$ in the third scenario is acting to control exports in order to alleviate "general or local short supply"? This query seeks to apply the Appellate Body's art Xx $(\mathrm{j})$ reasoning in India Solar Cells, whilst also determining the broader question whether Country Z's actions are in the public interest. For example, what was the total quantity of imports available to meet demand in Country Z? The answer to this query is clearly obvious: due to an international shortage, the sourcing of cotton yarn through imports was impossible and Country Z's cotton yarn producers emerged as top suppliers (both domestically and internationally). Therefore, this factor works in the favour of Country Z's export controls. Further, the extent to which international supply of a product is stable and accessible is to be considered. Again, the answer is similar to the previous query. The supplies are largely from domestic sources which also happen to be proximate to the market and production sites within the country. The Appellate Body explained in India - Solar Cells that, when determining "general or local short supply", the relevant factors are peculiar to each case. ${ }^{90}$

Also, the extent to which domestic producers sell their production abroad is a relevant factor which was identified by the Appellate Body. ${ }^{91}$ In the third scenario, cotton yarn producers were inclined to export their yarn rather than sell them domestically. These factors indicate that unless Country $\mathrm{Z}$ adopts export control measures, the domestic clothing sector will suffer immeasurably and may lead to rises in unemployment and business losses. Therefore, with the proviso that the measures are applied in a non-discriminatory manner, the export controls imposed by Country Z can potentially be considered as valid under $\operatorname{art} \mathrm{xx}(\mathrm{j})$ and could give grounds to resist any ISDS claims that Corporation $\mathrm{C}$ may bring against Country $\mathrm{Z}$ for indirect expropriation. Note, however, that Corporation $\mathrm{C}$ must distinguish confiscation from export controls. Export controls that may have been imposed by Country Z do not impose an outright ban

\begin{tabular}{l}
\hline $90 \quad$ India-Solar Cells, Appellate Body Report (n 7) [6.4]. \\
$91 \quad$ India-Solar Cells, Appellate Body Report (n 7) [5·71].
\end{tabular} 
on the exports of cotton yarn. Instead, like the export tariffs on the FOB price of rare earths discussed in the second scenario, they raise the export duty, with the aim of making exports unattractive for some exporters. Confiscation of property, on the other hand, is an outright taking which may be classified as direct expropriation. Therefore, if Country $\mathrm{Z}$ has confiscated any cotton yarn owned by Corporation $\mathrm{C}$ from the port warehouses, this may give rise to a claim for compensation even if the action was for a public purpose.

\section{$5 \quad$ Analysis}

\subsection{The Two Paths}

The challenge confronting any reader of this analysis is explaining the state actions from the several, and oft-competing, standpoints of "legitimacy", "necessity", "proportionality", "legitimate expectations", "public welfare" and/or "police powers". Are the three presented scenarios explained by the state exercising its regulatory powers, and/or is the state acting pursuant to a legitimate public purpose?

To answer this query, the exceptional grounds mentioned in GATT art Xx have to be holistically considered, since they share a conceptual similarity with common grounds of public regulation by states. Investment disputes such as the Methanex case indicate that "non-discriminatory regulation for public purpose" can be deemed by arbitral panels as falling within the doctrine of police powers. ${ }^{92}$ This is not different from public interest imperatives that the newer generation of FTAs and BITs refer to, while also constructing "carve out" clauses to make room for public welfare exceptions. ${ }^{93}$

The taxonomy of an export control is also important because there is a convincing line of arbitral cases that designate the exercise of police powers of state as non-compensable if done in a non-discriminatory manner. Conversely, the exercise of regulatory powers in order to promote public welfare objectives is recognised in some modern FTAs and BITs as not amounting to indirect expropriation. Hence, the actual procedure and the perception of the measure as being, or not being, in the public interest assumes greater importance.

92 See discussion in Methanex (Final Award) (n 71) 1456, cited in Mostafa (n 71) 272-274.

93 By way of illustration, ACIA (n 65) annex 2 (4) specifically provides for carve outs for "measures ... designed and applied to protect legitimate public welfare objectives such as public health, safety and the environment", which will not be considered to constitute expropriation. 
As far as export controls are concerned, the Appellate Body in the India Solar Cells case clarifies the meaning of "general or local short supply". Assuming the restrictions in question are applied uniformly and in a nondiscriminatory manner, the claim of a foreign investor for compensation may be on weak grounds. One possible solution suggested hereinabove was the incorporation or negotiation of stabilisation and/or economic equilibrium clauses in investment agreements, which will allow foreign investors to have their say in managing the fallout of any governmental measures. The first and second scenarios discussed previously illustrate that the application of export controls in this context will likely not be construed as expropriatory. However, such a simplistic approach creates some challenges.

Firstly, actual disruption must be proven by the host state. This may well become a key determinant connecting export controls and the foreign investor's claim for compensation for expropriation. In absence of a defined criterion, the government of the host state and the foreign investor may end up arguing their subjective interpretation of what is, or should be, the disruption that justifies the export controls. Whilst disruptions in the context of international trade can be handled under the GATT/WTO framework, no centrally agreed definitions exist in the realm of international investment law. Furthermore, FTAS/BITs may consider defining what a disruption may look like, but again there are no known FTAs or BITs that define disruption in a foreign investment context, particularly where the aim behind foreign investment in the host state is to enable foreign investors to export resources or goods.

Secondly, action in response to anticipated shortages or market disruptions may be difficult to justify, politically motivated or, quite simply, speculative in nature. Should a host state wait until actual disruption occurs, or is a risk assessment of impending shortage sufficient to impose export controls? This is a moot point, because foreign investors will argue that no actual disruption and/ or shortage has occurred, and hence that the imposition of export controls is expropriatory. Since there are no agreed formulae in international investment law to determine imminent market disruption, any attempt to speculate about the possible effects of market disruption in the absence of an actual one will likely be rejected by arbitral panels, as was the case with the Appellate Body's treatment of India's argument in India - Solar Cells case. ${ }^{94}$ Additionally, foreign investors and arbitral panels may attempt to interpret questions of public

94 India-Solar Cells, Appellate Body Report ( $\mathrm{n}$ 7) [5.76]. The panel in India-Solar Cells held that India "had not identified any actual disruptions", and that solar power developers ("SPDs") in India have not "experienced an actual disruption in supply": India - Solar Cells, Panel Report (n 20) [7.262]. 
interest when determining whether an "actual disruption" has occurred, or is likely to occur - a truly unsavoury proposition for most governments indeed. It is clear, from Australia's jousting with Phillip Morris, that well-endowed, multinational corporations ("MNCs") can exert substantial influence on governmental authorities, thereby resulting in regulatory chill. States and governmental authorities consider such fettering of their regulatory discretion an unwelcome prospect. ${ }^{95}$

Furthermore, there is a lack of general reporting mechanisms that enable the reporting of export controls to parties or countries affected by such measures. ${ }^{96}$ The ubiquitous means of notification are the news and electronic media that may be relied upon by business interests. While the WTO does maintain a Trade Policy Review Mechanism ("TPRM"), which records any export restrictions or controls in place, TPRM Reports usually come at a four-year interval for some countries (and six years for countries identified as LDCs). ${ }^{97}$ Clearly, this mechanism is not useful for the affected parties in circumstances where a government announces an export control, which may affect businesses dependent on goods or commodities that are subject to such controls. Considering the argument that export controls affecting MNCs owned by foreign investors may be subject to future disputes, it becomes worthwhile at this stage to discuss two possible paths for redress that may be chosen strategically by claimants.

\subsection{The First Path: WTo Dispute Settlement as a Parallel Action to ISDs}

Recourse to WTO dispute settlement by a foreign investor is based on the premise that export controls have breached GATT/WTO obligations owed to the country in which the foreign investor is based. This alternative poses several challenges. Firstly, the exact breach of wTO obligations must be ascertained, and the export controls in question must have violated the terms of the GATT/WTO framework (ie, the Most-Favoured-Nation ("MFN") or National Treatment ("NT") obligations, or the factors under GATT arts XI and XX, as explained through the WTO dispute-settlement jurisprudence). Secondly, the country in which the foreign investor is based must establish locus standi to bring about the complaint in the wTO. Thirdly, the wTO must grapple with a

\footnotetext{
95 Thirgood, Roche and Williams (n 85).

96 Matsushita, "Export Controls of Natural Resources and the wTo/GatT Disciplines" (n 8) 309 .

97 See generally "Uruguay Round Agreement: Trade Policy Review Mechanism (TrPM)", World Trade Organization (Web Page) <https://www.wto.org/english/docs_e/legal_e/29tprm_e.htm>.
} 
breach of obligations that, quite possibly, may be owed under a different bilateral FTA. ${ }^{98}$ This is where the foreign investor must assess its prospects of success, by investigating whether the underlying FTA contains a "fork-in-theroad"99 clause, which requires the investor (claimant) to select whether to lodge a claim for compensation in the domestic courts or opt for international options. ${ }^{100}$ However, "fork-in-the-road" clauses only enable selection between

98 This is a challenging proposition, as is illustrated by the Mexico - Soft Drinks case in the WTo. See Appellate Body Report, Mexico - Tax Measures on Soft Drinks and Other Beverages, wTo Doc WT/DS308/AB/R (6 March 2006) ("Mexico - Soft Drinks, Appellate Body Report”); Panel Report, Mexico - Tax Measures on Soft Drinks and Other Beverages, wTo Doc WT/DS308/R ( 7 October 2005) ("Mexico - Soft Drinks, Panel Report"). In Mexico - Soft Drinks, the US argued that domestic taxes imposed by Mexico on drinks using non-cane sugar breached the NT obligations that Mexico owed the US under GATT. Mexico justified its measures because the measures were in response to the US breaching its market access commitments negotiated under NAFTA on trade in sugar, while the US-origin high-fructose corn syrup ("HFCS") (a sugar alternative used as input in manufacturing of beverages) enjoyed continued preferential access to the Mexican market. Furthermore, Mexico claimed that the US continuously refused to submit to the NAFTA dispute settlement process. Resultantly, Mexico viewed the measures as falling within the scope of the GATT art Xx(d) exception, which permits a wTo Member to derogate from a GATT/WTO obligation to secure compliance with laws or regulations. The panel concluded that the tax breached the wTO NT obligation, but that the wTo has no jurisdiction to adjudicate on obligations owed under NAFTA: Mexico - Soft Drinks, Panel Report [4.70], [4.72], [8.193], [8.199]. The panel's conclusions were upheld on appeal by the Appellate Body. The Appellate Body disagreed with Mexico's argument on GATT art $\mathrm{xx}(\mathrm{d})$, and stated that the term "laws or regulations" in GATT art Xx $(\mathrm{d})$ referred "to the rules that form part of the domestic legal order of the wто Member invoking the provision and do not include the international obligations of another wTo Member": Mexico - Soft Drinks, Appellate Body Report [75], [79]-[8o]. See also detailed discussions in Sergio Puig, "The Merging of International Trade and Investment Law" (2015) 33(1) Berkeley Journal of International Law 1, 23-27; Roger Alford, "The Convergence of International Trade and Investment Arbitration" (2014) 12(1) Santa Clara Journal of International Law 35, 46-47.

99 "Fork-in-the-road" clauses enable foreign investors to bypass the standard rule of public international law that requires parties to exhaust domestic remedies before lodging an international claim: see, eg, discussion in Deborah Ruff and Trevor Tan, "Fork-in-TheRoad Clauses: Divergent Paths in Recent Decisions", Norton Rose Fulbright (Publication, October 2015) <http://www.nortonrosefulbright.com/knowledge/publications/132586/ fork-in-the-road-clauses >; see also the discussion in Christoph Schreuer, "Calvo's Grandchildren: The Return of Local Remedies in Investment Arbitration" (2005) 4(1) The Law \& Practice of International Courts and Tribunals 1, 3-5; Christoph Schreuer, "Travelling the BIT Route: Of Waiting Periods, Umbrella Clauses and Forks in the Road" (2004) 5(2) Journal of World Investment and Trade 231, 239-249.

100 Puig, above n 89, 36; Schreuer, above n 9o, 239-249; See further Norton Rose Fulbright, "Fork-in-the-Road clauses: Divergent Paths in Recent Decisions" (October 2015) <https:// www.nortonrosefulbright.com/en/knowledge/publications/obdioad8/fork-in-the-roadclauses $>$ (accessed 11 July 2019). 
enforcement alternatives, and do not concern treaty selection. ${ }^{101}$ Hence, the options for investors will be limited to local courts or redress under the operative FTA or BIT.

In the simulated scenarios discussed above, governmental actions were prompted by domestic compulsions in all three instances. If the act of imposing export controls is deemed a sovereign act, local courts will then be required to extend constitutional cover to cover the measures. Foreign investors will understandably be reluctant to approach domestic courts for redress. In the first and third scenarios especially, the government of the host state can refuse to pay any compensation by arguing that measures restricting exports were sovereign actions to alleviate "general or local short supply". If the matter proceeds to arbitration, the government can take up the plea that its export controls were an act of state. ${ }^{102}$

As stated above, the wTо dispute-settlement system can only be pursued as an alternative if there is a prima facie violation of GATT/WTO norms in the imposition of export controls. On rare occasions, and if the investors have enough financial resources along with significant influence, the aggrieved investor can pursue parallel claims under ISDS and WTO dispute settlement proceedings. ${ }^{103}$ Parallel proceedings may sometimes become necessary to secure comprehensive relief for the investors. For example, in the Mexico - Soft Drinks case, an action was pursued in the WTO alongside ISDS proceedings under NAFTA. Alford notes that in the case of Mexico imposing unlawful taxes on soft drinks, the WTO and NAFTA systems complemented each other in securing

\footnotetext{
101 Puig (n 98) 36.

102 This was recently illustrated in Reliance Industries Ltd and BG Exploration \& Production India Ltd $v$ India, in which the claimants (Reliance Industries and BG Exploration) lodged an arbitration claim against the respondent government (India) for unpaid sums due on production sharing contracts. After the tribunal found that it lacked jurisdiction to determine the question of legality of the government ordering its subordinate departments to withhold payments, the matter was appealed to the Queen's Bench Division, Commercial Court in England. Popplewell J held that the issues in question were covered under the foreign-act-of-state doctrine and were thus non-justiciable before the court and non-arbitrable before the tribunal. This decision underscores the application of act of state doctrine in arbitration as well as court proceedings. The implication of the decision is that a state party intending to avoid performance under a contract can easily issue executive orders, ordinances or legislation and then invoke the act-of-state principle in any proceedings where the seat of arbitration is in England: see generally Reliance Industries Ltd and BG Exploration \& Production India Ltd v India [2018] EWHC 822 (Comm); see also Lucia Raimanova and Matej Kosalko, "Act of State Doctrine Applies in Arbitration", Allen \& Overy (Web Page, 21 June 2018) < http://www.allenovery.com/publications/en-gb/ |Pages/Act-of-State-doctrine-applies-in-arbitration.aspx $>$. 
both prospective and retroactive relief for the investors. ${ }^{104}$ If the wTO had been the only system used to adjudicate the dispute, then the wTo Appellate Body's direction to Mexico, to repeal the unlawful taxes, would have been the end of the matter. However, parallel claims under arbitration enabled the aggrieved investors to collectively receive approximately USD170 million in damages in three separate claims. ${ }^{105}$

Another recent example concerns the action launched by Cuba, Indonesia, Ukraine, Honduras and Dominican Republic against the Australian tobacco plain-packaging legislation in the wTO, alleging violation of the WTO's Agreement on Trade-Related Aspects of Intellectual Property Rights. ${ }^{106}$ This action was launched in parallel to ISDs proceedings instituted by Philip Morris under the Hong Kong-Australia BIT. ${ }^{107}$ Sergio Puig terms this behaviour of MNCs as "party shopping", whereby private parties strategically select a state party to espouse a claim on their behalf in the wT $0 .{ }^{108}$

104 Alford (n 98) 47 .

105 Three claims cited by Alford (n 98) 47 are: (i) Archer Daniels Midland Co et al $v$ Mexico (Award) (ICSID Arbitral Tribunal, Case No ARB(AF)/04/05, 21 November 2007), where the tribunal awarded USD 33 million in damages to the Claimant; (ii) Corn Products International Inc v Mexico (Decision on Responsibility) (ICsID Arbitral Tribunal, Case No $\mathrm{ARB}(\mathrm{AF}) / 04 / 01,15$ January 2008), where the tribunal awarded USD58.4 million in damages; and (iii) Cargill Inc v Mexico (Award) (ICSID Arbitral Tribunal, Case No $\mathrm{ARB}(\mathrm{AF}) / 05 / 02$, 18 September 2009), where the tribunal awarded USD 77.3 million in damages.

106 See generally Panel Report, Australia - Certain Measures Concerning Trademarks, Geographical Indications and Other Plain Packaging Requirements Applicable to Tobacco Products and Packaging, WTO Doc WT/DS435/R; WT/DS441/R; WT/DS458/R; WT/DS467/R (28 June 2018). In this case, the WTO panel endorsed Australia's plain packaging laws by holding that they contributed to improving public health by reducing and discouraging use of tobacco products: [7.228]-[7.232], [7.1725], [7.1731], [7.2794]-[7.2795]; see also "Australia Wins Landmark World Trade Organisation Ruling on Tobacco Plain Packaging Laws", ABC News (Web Page, 28 June 2018) <http://www.abc.net.au/news/2018-o6-29/ australia-wins-landmark-wto-ruling-on-tobacco-plain-packaging/9921972>.; Marrakesh Agreement Establishing the World Trade Organization, opened for signature 15 April 1994, 1867 UNTS 3 (entered into force 1 January 1995) annex 1C ("Agreement on Trade-Related Aspects of Intellectual Property Rights") ("TRIPS Agreement").

107 See generally Philip Morris Asia Ltd v Australia (Award on Jurisdiction and Admissibility) (Permanent Court of Arbitration, Case No 2012-12, 17 December 2015); Agreement between the Government of Australia and the Government of Hong Kong for the Promotion and Protection of Investments, signed 15 September 1993, [1993] ATs 30 (entered into force 15 October 1993).

108 Puig (n 98) 36; Alford observes that one of the complainants in the WTO case (Ukraine) had not exported tobacco to Australia in recent years: Alford (n 98) 50. British American Tobacco was known to be assisting Ukraine with its legal costs in the wTO claim because MNCS currently have no standing to lodge a wTO claim. Ukraine eventually dropped the 
Parallel proceedings usually involve MNCs with significant resources engaging in a protracted dispute-resolution process. Pursuing such a strategy is based on a careful study of costs and benefits. In the simulated scenarios, all three affected businesses will have to determine whether they wish to pursue a strategy based on ISDS coupled with a WTO claim. For the parallel action strategy to work, the MNCs in question will have to lobby their governments to bring about a state-based response in the wTO, which is a difficult proposition due to the largely self-regulating nature of WTO dispute-settlement system. ${ }^{109}$

\subsection{The Second Path: ISDs Adapting wTo Dispute-Settlement Jurisprudence as an Interpretative Aid (Convergence)}

Given the challenges of adopting the approach outlined above, investors may consider "borrowing" arguments from wTO jurisprudence when pursuing their ISDS claim against the host state. China-Rare Earths and China - Raw Materials have demonstrated that the WTO remains interested in promoting the fair and equitable allocation of resources between domestic users and importers. However, the challenge in cross-implementing the wто standards in investment disputes is a grey area. If disputes on export controls remain within the realm of international trade, GATT/WTO norms may provide a prospective solution (ie, the WTO DSB recommending that the offending WTO member brings its impugned measures in line with its WTO obligations). It is only when the export control disputes encroach into the field of international investment law that there are no clear characterisations of the issue, primarily because there are no international agreements addressing the relationship between export controls and expropriation. The meaning of expropriation has been left to individual BITs and FTAs and the interpretation of arbitral tribunals. Decisions issued in the past by the ISDs tribunals have done little to resolve the question of whether the host country remains the master of their natural resources or becomes subject to the requirement of an equitable distribution of resources after signing BITs and/or FTAs.

claim against Australia, citing hopes of finding a mutually agreed solution with Australia: "Ukraine Drops Lawsuit against Australia over Plain-Packaging Tobacco Laws, WTo Says", ABC News (Web Page, 3 June 2015) <http://www.abc.net.au/news/2015-06-04/plain-pac kaging-tobacco-ukraine-drops-lawsuit-against-australia/652016o $>$.

109 Puig (n 98) 36-37, citing Appellate Body Report, Mexico - Anti-Dumping Investigation of High Fructose Corn Syrup from the United States - Recourse to Article 21.5 of the DSU by the United States, wTO Doc WT/DS132/AB/RW (22 October 2001) [73]-[74], wherein the Appellate Body deemed that the request for establishment of panel by a wTO Member is premised on good faith and an exercise of sound judgment regarding the utility of dispute settlement process under the WTO system. 
Future arbitral panels confronted with the question of export controls and indirect expropriation may consider "importing" or "transplanting" the interpretation of the concept of a local or general short supply of materials from GATT/WTO norms. ${ }^{110}$ The interpretation of GATT art $\mathrm{xx}(\mathrm{j})$ by the Appellate Body in India - Solar Cells (especially in para [6.4]) may provide a useful initial point. The concluding comment in para [6.4], namely, "whether and which factors are relevant necessarily depend on the particularities of each case", can be termed as a control valve for the application of the standard to determine whether an export control can be justified based on "local or general short supply" similar in spirit to the chapeau of GATT art Xx. This is just a starting point. The remaining development of the concept will then, it is hoped, assume a more organic trajectory in the form of arbitral panel decisions and their impacts on future BITs and FTAs. The adoption of GATT $\operatorname{art} \mathrm{xx}(\mathrm{j})$ reasoning can further enable policymakers in host states to construct WTO- and/or BITcompliant export controls in a manner that limits the possibility of challenges by foreign investors.

The approach of importing from wTO jurisprudence has not only been considered by arbitral panels in the past, but has received growing academic attention in recent years, resulting in a "convergence" of international trade and investment law. ${ }^{111}$ This is not to suggest that the convergence approach finds total approval. It is merely a course of action which can be considered as an initial point in international investment dispute resolution where there are ambiguities in law or an absence of jurisprudence on an issue.

110 The underlying assumption is that export controls were imposed for alleviating local shortages or for domestic price stabilisation. Puig terms this approach as "transplantation", whereby disputing parties may import a rule from one trade treaty to another investment treaty. Puig cites the example of the strategy employed by Philip Morris, linking Australia's obligations under the Hong Kong-Australia BIT with Australia's WTo obligations under the TRIPS Agreement and the Agreement on Technical Barriers to Trade (Marrakesh Agreement Establishing the World Trade Organization, opened for signature 15 April 1994, 1867 UNTS 3 (entered into force 1 January 1995) annex 1A ("Agreement on Technical Barriers to Trade")): Puig (n 98) 41-44.

111 Jurgen Kurtz, "The Use and Abuse of wTo Law in Investor-State Arbitration: Competition and its Discontents" (2009) 20(3) European Journal of International Law 749, 751-759, 770771; Robert Howse and Efraim Chalamish, "The Use and Abuse of wTo Law in InvestorState Arbitration: A Reply to Jurgen Kurtz" (2010) 20(4) European Journal of International Law 1087, 1088-1090; Alford (n 98) 37; Frank Garcia et al, "Reforming the International Investment Regime: Lessons from International Trade Law" (2015) 18(4) Journal of International Economic Law 861, 864; Brooks Allen and Tommaso Soave, "Jurisdictional Overlap in wто Dispute Settlement and Investment Arbitration" (2014) 30(1) Arbitration International 1, 28; Andrea Bjorklund, "Convergence or Complementarity" (2013) 12(1) Santa Clara Journal of International Law 65, 68-70; Puig (n 98) 4-5. 
By way of illustration, ISDS proceedings on NT issues show that disputesettlement tribunals are hesitant to adopt wTO jurisprudence to explain NT in an FTA and/or BIT context. For example, in Pope and Talbot $v$ Canada, the respondent (Canada) attempted to base its arguments on the NT standard under WTO law and import the same understanding in its dispute regarding softwood lumber with a US-based investor under NAFTA. ${ }^{112}$ Canada specifically claimed that even where the foreign investor was awarded a lower quota than domestic producers, there was no discrimination because foreign investors were not disadvantaged disproportionately as a group. ${ }^{113}$ Kurtz observes that Canada's arguments imply that the impact of a measure must be determined by comparing two basic groups (local producers and foreign investors) to assess any disproportionate impact on foreign investors as a whole. ${ }^{114}$ In its analysis, the tribunal rebutted Canada's argument that the disproportionate disadvantage test was grounded in WTо jurisprudence. ${ }^{115}$ The tribunal specifically pointed out that the disproportionate disadvantage test was unwieldly and posed practical obstacles in its implementations. In particular, the tribunal stated that if Canada's arguments were adopted, this would mean that the foreign investor would have to undertake the mammoth task of tracking the quota details of US-owned companies in Canada and then consider the treatment being accorded to those companies as a whole in contrast with domestic companies operating in like circumstances. ${ }^{116}$ The tribunal concluded that, were this the approach to be taken, "only in the simplest and most obvious cases of denial of national treatment could the complainant hope to make a case for recovery".117 Based on Pope and Talbot v Canada alone, and contrasting the three alternative scenarios provided in this article, a foreign corporation could consider making parallel arguments based on WTO laws, alongside an IsDs claim, that export controls by host states are discriminatory and amount to indirect expropriation, if it can be demonstrated that local actors are being advantaged.

Note, however, that this strategy may encounter practical difficulties for the aggrieved investors. The example being discussed here shows the potential possibilities, but not necessarily a practical strategy. Other disputes where the convergence approach was considered encountered cautious responses by the relevant dispute settlement tribunals. For example, in another NAFTA dispute,

\footnotetext{
112 See Pope \& Talbot Inc v Canada (Award on the Merits of Phase 2) (Ad Hoc Tribunal under the UnCitral Arbitration Rules, 10 April 2001) [43]-[44] ("Pope \& Talbot v Canada").

113 Kurtz (n 111) 761.

114 Pope \& Talbotv Canada (n 112) [46]-[63].

115 Ibid.

116 Ibid [71]-[72]; Kurtz (n 111) 762.

117 Pope \& Talbot v Canada (n 112) [71]-[72]; Kurtz (n 111) 762.
} 
SD Myers $v$ Canada, the tribunal cited the Appellate Body's treatment of "like" circumstances in Japan - Taxes on Alcoholic Beverages, wherein the Appellate Body had commented that: ${ }^{118}$

[T] here can be no one precise and absolute definition of what is "like". The concept of "likeness" is a relative one that evokes the image of an accordion. The accordion of "likeness" stretches and squeezes in different places as different provisions of the wTO Agreement are applied.

The tribunal observed that similar to the GATT treatment of "like", the overall legal context provided by the FTA (in this case NAFTA) and any other treaties must be considered carefully. ${ }^{119}$ The tribunal pointed out that all three NAFTA countries are also part of the Organisation of Economic Co-operation and Development ("OECD") and hence, the OECD Declaration on International and Multinational Enterprises becomes relevant as well in determining the question of "like" circumstances. ${ }^{120}$

In the well-known Methanex dispute, the tribunal considered the wto concept of NT in order to determine the connection between "like circumstances" and "like products". ${ }^{121}$ The tribunal in Methanex specifically observed that "if the drafters of NAFTA had wanted to incorporate trade criteria in its investment chapter by engrafting a GATT-type formula, they could have produced a version of Article 1102". ${ }^{122}$

118 Appellate Body Report, Japan - Taxes on Alcoholic Beverages, wTo Doc WT/DS8/AB/R; WT/DS10/AB/R; WT/DS11/AB/R (4 October 1996) 21 (“Japan - Alcoholic Beverages, Appellate Body Report"), cited in SD Myers v Canada (Partial Award) (North American Free Trade Agreement Tribunal under the UnCITrAL Arbitration Rules, 13 November 2000) [244] ("SD Myers v Canada").

119 SD Myers $v$ Canada (n 118) [245], [248].

120 The $O E C D$ Declaration on International and Multinational Enterprises dealt with the "like situation" test by affirming that

[T] he comparison between foreign-controlled enterprises is only valid if it is made between firms operating in the same sector. More general considerations, such as the policy objectives of Member countries could be considered to define the circumstances in which comparison between foreign-controlled and domestic enterprises is permissible inasmuch as those objectives are not contrary to the principle of national treatment ... Ibid [249], citing the 1993 version of Organisation for Economic Co-operation and Development, OECD Declaration on International Investment and Multinational Enterprises, 21 June 1976 .

121 Kurtz (n 111) 763-765; Methanex (Final Award) (n 71) 1447-1448.

122 Methanex (Final Award) (n 71) 1447-1448. 
More specifically, the tribunal noted that it was apparent from the text that the drafters of NAFTA were careful about the inclusion of the terms such as "like goods", "any like, directly competitive or substitutable goods" and "like circumstances". ${ }^{123}$ The tribunal observed that "like goods" is not used within the context of Ch 11 (investment), while "like circumstances" (which is used as an expression in art 1102, within $\mathrm{Ch}$ 11) is used for investment, with respect to standards related to measures constituting technical barriers to trade ("TBTs"), only in relation to services but not in relation to goods. ${ }^{124}$

Roger Alford comments that regardless of whether the tribunals in Pope and Talbot, SD Myers and Methanex reached the correct result, these leading cases presumed the relevance of WTO jurisprudence and that comments that the "pull toward reliance on WTO as persuasive authority appears almost irresistible". ${ }^{125}$ Alford also cites comments by a dissenting arbitrator in UPS $v$ Canada, who argued that the wording of NAFTA art 1102 suggests a close connection to NT standards in GATT and the General Agreement on Trade in Services ("GATS"), as well as other international trade and investment treaties. ${ }^{126}$ The dissenting arbitrator views this as a reading consistent with precedent under GATT and WTO. ${ }^{127}$

It is noticeable that the NAFTA cases discussed above are based on the issue of NT between domestic industries and foreign investor-owned businesses aggrieved by governmental measures. The simulated scenarios in this article differ significantly, in that they deal with export controls which curtail foreign investors' ability to export. The scenarios have assumed that the export controls due to "local and general short supply" have equally affected the local industries, hence, a breach of NT can be set aside as a non-issue. Since export controls are not mentioned in any FTA or BIT specifically, in the absence of any express provisions, the standard discussed by the Appellate Body in India Solar Cells can be considered as a close guide as to how they will be treated by an international investment tribunal.

The convergence approach, however, brings its own complications. According to some commentators, the approach of borrowing GATT/WTO of America Inc $v$ Canada (Award on the Merits) (Separate Statement of Dean Ronald Cass) (North American Free Trade Agreement Chapter 11 Tribunal, 24 May 2007) [57]-[61] $<$ https://arbitrationlaw.com/sites/default/files/free_pdfs/UPS\%20v\%20Canada\%20Merits.pdf $>$.

127 Ibid.
} 
jurisprudence requires sophisticated analysis by qualified individuals in the area, in order to minimise any inconsistencies in awards. ${ }^{128}$ Kurtz opines that "serious, real-world implications" result from the cross-application of GATT/WTO jurisprudence in investment disputes without a proper understanding of the underlying norms. He cites Argentina's liability of millions of dollars due to "objective evidence of legal error" on the part of tribunals, which eventually resulted in the Latin American backlash to the International Centre for Settlement of Investment Disputes system. ${ }^{129}$

The attempt to connect wTO law with international investment disputes has received some criticism as well. In the context of the US-Argentina BIT and the claims for compensation by investors thereunder, the practice of drawing from wTO jurisprudence carries the merit of applying an internationally used standard which may be preferable to the prospect of applying domestic law of the host state to the dispute. ${ }^{130}$ However, there were no reasons to assume that drafters of the US-Argentina BIT intended to connect modern WTO law to BIT disputes. ${ }^{131}$ This is mainly because the meaning of "necessary" in

128 Kurtz cites the instance of the presiding arbitrator in Continental Casualty Company $v$ Argentina who had served on the wTo Appellate Body: Kurtz (n 111) 771, citing Continental Casualty Company v Argentina (Award) (ICsID Arbitral Tribunal, Case No ARB/03/9, 5 September 2008), 85-89, [193]-[199]; see also Puig (n 98) 29; Alec Stone Sweet, "InvestorState Arbitration: Proportionality's New Frontier" (2014) 4(1) Law \& Ethics of Human Rights 48, 49, 69-75 (Sweet terms the analysis by the tribunal in Continental Casualty as a "rich piece of jurisprudence, far more sophisticated than the awards produced in ... previous cases"). In Continental Casualty, Argentina defended its regulatory measures as necessary and relied upon the comparative definition of the term "necessary" under GATT art $\mathrm{Xx}$ for explaining the effect of art XI in the Treaty between United States of America and the Argentine Republic Concerning the Reciprocal Encouragement and Protection of Investment, signed 14 November 1991 (entered into force 20 October 1994). The arbitral panel applied the WTO jurisprudence regarding GATT art Xx from previous cases such as Korea - Beef and Brazil - Retreaded Tyres in explaining the terms "necessary" and "necessity".

129 For example, the leading economy in Latin America (Brazil) has refused to ratify the Convention on the Settlement of Investment Disputes between States and Nationals of Other States, opened for signature 18 March 1965, 575 UNTS 159 (entered into force 14 October 1966) ("ICsID Convention"). Other resource-rich developing economies in Latin America such as Bolivia, Ecuador and Venezuela withdrew from the ICSID Convention and Argentina threatened to withdraw (but has not withdrawn) from the ICSID Convention: see also Kurtz (n 111) 771; Jurgen Kurtz, "Adjudging the Exceptional at International Law: Security, Public Order and Financial Crisis” (Working Paper o6/o8, Jean Monnet Program, 2008) $25^{-29}$.

130 See the discussion in José E Alvarez and Kathryn Khamsi, "The Argentine Arisis and Foreign Investors: a Glimpse into the Heart of the Investment Regime” (Working Paper 2008/5, Institute for International Law and Justice, 2008) 54-55. Ibid. 
GATT art XX is linked to a balancing test, implied in the preamble of that provision, which is missing from art XI of the US-Argentina BIT. ${ }^{132}$ The thrust of this criticism seems to be that importing GATT/WTO norms into a BIT dispute is not merited, because the underlying treaty framework is affected by how operative clauses are interpreted in light of its substantive content.

Regardless of the two paths taken in resolving investment disputes on export controls, the field remains open to different interpretations and independent variables that may affect the outcome of disputes in the future. Multiple perspectives can determine the validity of export controls, which can affect the legality of the measures challenged in an IsDs setting. For host states, the question of imposing export controls must be looked at by policymakers through the lens of legitimacy and necessity. The experience of GATT/WTO jurisprudence and various arbitral awards is particularly illustrative for policymakers in constructing measures that remain within the GATT/WTO framework, while also remaining true to any applicable norms set by bilateral FTAs and/or BITs. It is fully possible that the resolution of points of contention in investment disputes may involve adjudication through transplanted norms from the GATT/WTO system. Additional complications can also stem from the selective citation of arbitral awards in previous investment disputes. The task of constructing legitimate and justifiable export control measures is, therefore, a difficult one for host states.

Conversely, the foreign investors can approach the process of challenging export controls from both a trade and investment angle. The obvious proviso is that foreign investors must possesses enough resources along with influence to trigger a state-based espousal on their behalf in the wTо. Investment arbitration can never be assumed to be fully self-contained system, even when modern FTAs and BITs are becoming increasingly prescriptive. ISDS panels cannot ignore the general norms and rules of international law in the arbitral process. ${ }^{133}$ Additionally, the arbitral process suffers from a lack of any precedent-creating systems which could assure consistency for users of the

\footnotetext{
$132 \quad$ Ibid 55 .

133 Margie-Lys Jaime, "Relying Upon Parties" Interpretation in Treaty-Based Investor-State Dispute Settlement: Filling the Gaps in International Investment Agreements' (2014) 46(1) Georgetown Journal of International Law 261, 272-277.
} 
system. ${ }^{134}$ With state-based espousal in the wTO a difficult proposition, the aggrieved foreign investor may wish to consider importing parallel arguments from the realm of international trade to reinforce their claims. For policymakers in host states, this means that design of export controls must be such that it remains compatible with trade and investment obligations.

134 Ibid 277-278; see generally the discussion in Alain Pellet, "Annulment Faute de Mieux: Is there a Need for an Appeals Facility?" in N Jansen Calamita, David Earnest and Markus Burgstaller (eds), The Future of ICSIBID and the Place of Investment Treaties in International Law: Current Issues in Investment Treaty Law (British Institute of International and Comparative Law, 2013) bk 4255. 